Austerity and the Rise of the Nazi party

Gregori Galofré-Vilà, Christopher M. Meissner, Martin McKee, and David Stuckler

NBER Working Paper No. 24106

December 2017, Revised in September 2020

JEL No. E6,N1,N14,N44

\begin{abstract}
$\underline{\text { ABSTRACT }}$
We study the link between fiscal austerity and Nazi electoral success. Voting data from a thousand districts and a hundred cities for four elections between 1930 and 1933 shows that areas more affected by austerity (spending cuts and tax increases) had relatively higher vote shares for the Nazi party. We also find that the localities with relatively high austerity experienced relatively high suffering (measured by mortality rates) and these areas' electorates were more likely to vote for the Nazi party. Our findings are robust to a range of specifications including an instrumental variable strategy and a border-pair policy discontinuity design.
\end{abstract}

Gregori Galofré-Vilà

Department of Sociology

University of Oxford

Manor Road Building

Oxford OX1 3UQ

United Kingdom

galofrevila@unibocconi.it

Christopher M. Meissner

Department of Economics

University of California, Davis

One Shields Avenue

Davis, CA 95616

and NBER

cmmeissner@ucdavis.edu

\author{
Martin McKee \\ Department of Health Services Research \\ and Policy \\ London School of Hygiene \\ \& Tropical Medicine \\ 15-17 Tavistock Place \\ London WC1H 9SH \\ United Kingdom \\ martin.mckee@1shtm.ac.uk \\ David Stuckler \\ Università Bocconi \\ Carlo F. Dondena Centre for Research on \\ Social Dynamics and Public Policy (Dondena) \\ Milan, Italy \\ david.stuckler@unibocconi.it
}




\title{
Austerity and the Rise of the Nazi party
}

\author{
Gregori Galofré-Vilà \\ Christopher M. Meissner \\ Martin McKee \\ David Stuckler
}

\begin{abstract}
We study the link between fiscal austerity and Nazi electoral success. Voting data from a thousand districts and a hundred cities for four elections between 1930 and 1933 shows that areas more affected by austerity (spending cuts and tax increases) had relatively higher vote shares for the Nazi party. We also find that the localities with relatively high austerity experienced relatively high suffering (measured by mortality rates) and these areas' electorates were more likely to vote for the Nazi party. Our findings are robust to a range of specifications including an instrumental variable strategy and a border-pair policy discontinuity design.
\end{abstract}

Keywords: Austerity, Nazis, Radical Voters, Dictatorship.

JEL Code: N14, N34, N44, D7, D72.

Earlier versions of this paper were presented at the Australian National University, Bocconi University, Hitotsubashi University, Humboldt University, NBER, New York University, New York University-Shanghai, Shanghai University of Finance and Economics, UC Berkeley, UC Davis, UC Irvine, UCLA, University of Groningen, University of Michigan and the 2018 World Economic History Congress. We thank Maja Adena, Barbara Biasi, Dan Bogart, Fabio Braggion, Barry Eichengreen, Ruben Enikolopov, Harold James, Sanford Jacoby, Peter Lindert, Dan Liu, Petra Moser, Maria Petrova, Burkhard Schipper, Nico Voigtländer, HansJoachim Voth and Noam Yuchtman, for a series of constructive suggestions.

Gregori Galofré-Vilà, Universitat Pompeu Fabra, Department of Economics and Business and Barcelona Graduate School of Economics, gregori.galofre@upf.edu. Christopher M. Meissner, Department of Economics University of California, Davis and NBER, cmmeissner@ucdavis.edu. Martin McKee, Department of Health Services Research and Policy, London School of Hygiene \& Tropical Medicine, martin.mckee@lshtm.ac.uk. David Stuckler, Dondena Centre for Research on Social Dynamics and Public Policy and Department of Policy Analysis and Public Management, University of Bocconi, david.stuckler@unibocconi.it. 


\section{Introduction}

In 1928 the German Nazi party earned just over two percent of the votes in the general federal elections. By mid-1932 it had received 38 percent of votes in the national elections becoming the largest political party in the Reichstag. How did this shift to the extreme far-right happen so quickly? Economic factors like high unemployment associated with the Great Depression, socio-cultural issues, and the excessively punitive Treaty of Versailles are well studied. They undoubtedly played an important role in the rise of the Nazi party. Still, the rapid growth of support for the Nazi party well into the Great Depression remains the subject of considerable debate (Eichengreen 2018; Ferguson 1996; James 1986; Satayanth et al. 2017; Temin 1990; Voth 2020).

In this paper we investigate the association between the austerity measures implemented by the German government between 1930 and 1932 and voters' increased support for the Nazi party. A growing literature studies the interactions between political preferences and fiscal policy with evidence that austerity packages are correlated with rising extremism (Alesina et al. 2019; Bor 2017; Eichengreen 2015, 2018; Fetzer 2019; Ponticelli and Voth 2020). It stands to reason that the austerity measures implemented in Germany in the early 1930s played a role. However, there is no direct quantitative assessment of this issue for the Weimar republic of which we are aware.

During this period, Heinrich Brüning of the Center Party, and Germany's chancellor between March 1930 and May 1932, implemented a set of measures via executive decree in order to balance the country's finances. These austerity measures included real cuts in spending and transfers as well as higher tax rates. According to Brüning, the consequent

suffering would be highly visible, thereby eliciting international sympathy for the Germans and helping put an end to the unpopular reparations imposed at Versailles (Evans 2003).

To test the hypothesis that austerity can explain increased Nazi vote share, we use city and district level election returns for the federal elections of 1930, 1932 (July and November) and 1933. We then link local vote shares to different proxies for city, district and state-level fiscal policy changes while also controlling for other potential explanations for the rise of 
the Nazis, such as unemployment, changes in wages and economic output. Our results are robust to inclusion of a number of different controls and specifications including city-level time trends, state by year fixed effects and electoral district by year fixed effects.

The observational data we use to study austerity and extremism have a number of features which enable us to overcome obvious issues of reverse causality and endogeneity. Brüning's policies on spending and taxes were not expected. Instead they became an outcome of the unexpectedly severe economic and financial crisis. They were decided at the Reich level by Brüning and his cabinet with implicit support of the Reichstag. Spending cuts and tax rise were uniformly applied across the nation so that the policy decisions were exogenous to the preferences of specific cities and districts. As noted by Balderston (1993: 225) 'the progressive 'nationalization' of taxing and spending decisions, justifies historians in the responsibility they place on the Brüning cabinet and on Brüning personally, for the fiscal balance during the slump."

Limits on spending and on changes to taxes, policy variables often formerly controlled by local authorities, were also imposed. Successive pay cuts to national civil service salaries are an example. Although some expenditure cuts were out of the hands of localities and mandated by the national government, some budget categories were hit harder than others. This fact means that nationally imposed budget cuts might have differential impacts on localities depending on the pre-determined patterns of spending and reliance on the national government for transfers to fund different categories of spending. We use city-level variation in the pre-austerity reliance on Reich transfers and national changes in transfers as a shiftshare instrumental variable for subsequent spending declines. Since states, localities and the central government were unable to borrow on international capital markets after 1930 (Schuker 1988), localities were forced by markets to traverse the depression with highly disruptive fiscal shocks.

As for taxes, a similar logic applies. The Reich maintained control over a number of specific taxes determining, for example, the statutory marginal rates for income taxes and corporation turnover taxes. Changes to the statutory marginal rates applied equally and evenly to all states and localities, but lower brackets had higher percentage increases in in- 
come tax rates (Newcomer 1936). We use variation at the local level in the initial distribution of taxable income across tax brackets and national changes in tax policy to instrument for the austerity-driven tax hikes. To make identification valid, we need to avoid confounding our fiscal shock with an unobservable economic shock correlated with income distribution. On the income distribution, Dell (2007) and Gómez-León and de Jong (2019), show that Gini coefficients and top income shares were fairly constant between 1928 and 1933.

Higher Nazi vote share could be because of resentment arising from distributional battles for slices of the fiscal pie in difficult times. There is clearly a distributional component to these changes, the percentage rise in tax rates being much higher for the lower income brackets. Wueller (1933) also discusses that while tax revenue had traditionally been retained where it was collected, intra-state redistribution was increasingly becoming need based during the Depression.

We also use a number of different econometric specifications to eliminate further concerns about endogeneity. We employ both city/district fixed effects models and long differences to focus on within locality variation in Nazi support. We are also able to circumscribe the control group by matching districts to neighboring districts just across state borders as in Dube et al. (2010). While relevant observables were spatially smooth, fiscal policy across the state borders was sharply different because state policies responded to state-wide concerns. With this identification strategy, we are also able to control for common economic shocks correlated with the initial characteristics of localities by using period by district-pair fixed effect interaction terms. Even after controlling for local economic shocks between 1930 and 1932 in this way, austerity remains a statistically, economically, and politically significant determinant of Nazi vote share.

We also provide some novel quantitative estimates concerning the channels by which austerity mattered. To do so, we study the relationship between mortality rates and austerity. We find a plausible link since where public spending on health care dropped more, mortality was higher. These places also saw a relatively large increase in Nazi support at the polls. Finally, looking at archival documents of Nazi propaganda, we document how Nazi leaders invoked austerity to attack Brüning and the Weimar Republic and how Brüning's tax rises 
were seen as inefficient and unfair by the German masses.

Even though there has been a German debate on whether there was an alternative to austerity (Borchardt 1980; Büttner 1989; Ritschl 1998; Voth 1993) and speculation that austerity played a role in the rise of the Nazi party, to our knowledge no previous research has directly tested the quantitative impact and the channels by which fiscal austerity mattered. Falter et al. (1986), Frey and Weck (1981), King et al. (2008) and Stögbauer and Komlos (2004) studied the economic shocks of the period but did not use fiscal data and the transmission mechanisms emphasized are different from ours. Previous work focused on a direct channel from lower disposable incomes and unemployment to frustration at the polls. On global comparisons, one study evaluated the impact of the Great Depression and austerity on voting patterns in 171 elections in 28 countries (Bromhead et al. 2013) and another looked at the European level (Ponticelli and Voth 2020). Yet these have not considered the particular context of Weimar Germany.

Regarding the connection between political competition and differential effects of the crisis, the literature notes that the lowest status groups and the unemployed turned to the Communists (Falter et al. 1986, King et al. 2008), but those just above in the economic hierarchy, who had more to lose from the tax hikes and spending cuts, seem to have favored the Nazis. Between 1930 and 1933 the Nazis gained votes from all walks of life. Yet, Evans (2003), Falter et al. (1986), King et al. (2008), Voigtländer and Voth (2019) have documented how the party was 'underrepresented' among the working classes, in industrial cities, and in Catholic regions. We control for these fixed factors and allow for interactions between them and our measures of austerity.

Our baseline results show that Brüning's austerity had a sizable effect. Each one standard deviation increase in austerity was associated with between one quarter to one half of one standard deviation of the dependent variable. In localities where austerity was more severe, Nazi vote share was significantly higher. Our novel use of within locality variation in the size of the fiscal shock, sheds light on the local and national experience of democratic decline.

The rest of the paper is as follows. In the next section we provide a detailed account of the main existing explanations for the rise of the Nazis. Section 3 reviews how austerity 
was implemented and Section 4 presents the historical context of the different elections in Germany between 1930 and 1933. In Sections 5 and 6 we show our main results and robustness checks for the city- and district-level outcomes using spending and tax data. Section 7 concludes.

\section{Competing explanations}

There are many competing explanations for the stark rise of the Nazi party in Weimar Germany. The conventional explanation is the impact of the Great Depression. Those hit hardest by the economic downturn held the incumbent parties responsible for their situation, punishing them by voting for the Nazi party. Economic activity peaked in Germany in 1928, driven by a sharp downturn in investment (Ritschl 2002; Temin 1971). Later, the cessation of capital inflows and a crisis in the German banking sector culminated in a slowdown in the growth of credit, while other international shocks prolonged the downturn. Yet, the unwillingness of the Reichsbank to stop the deflation mattered but cannot necessarily explain regional variation in Nazi support.

A similar point could be made with respect to the increasing numbers of unemployed workers, soaring from 1.4 million in 1928 to 5.6 million in 1932. Unemployment also reached very high levels in other countries such the United States around that time, without being accompanied by electoral radicalization (Eichengreen and Hatton 1988). Additionally, unemployed were more likely to vote for the Communist party or the Social Democrats (in Protestant precincts) rather than the Nazi party (Evans 2003; King et al. 2008), as the Communist party was perceived as the party that traditionally represented workers' interests.

A third explanation invokes resentment about high debt repayments imposed on Germany in the Treaty of Versailles. These debts initially totaled up to 260 percent of 1913 GDP (Ferguson 1997; Ritschl 2013). Although France and Britain had war debt burdens similar to Germany, the Versailles agreements treated Germany as a conquered enemy, forcing it to pay a large share of the allies' costs of the war. This placed financial demands on Germany 
that were very difficult to meet and which were dubbed as 'cruel' by some (Keynes 1920; Temin and Vines 2014). However, Germany's war debts were never completely paid (GalofréVilà et al. 2019). German war debts were postponed in the Hoover moratorium of 1931 or temporarily suspended in the Lausanne Conference a year later ${ }^{1}$

Fiscal austerity might simply have been a driver of economic collapse if multipliers were large enough, but Ritschl (2013) reports that these were small. If austerity mattered, it must have been something about the unique way Germany experienced it. Even if austerity did not have a contractionary effect on aggregate demand, it still might have had distributional consequences that in turn affected how people voted. Austerity not only hurt the lower middle classes and elites, by increasing tax rates on profits and income, but ostensibly also had a major impact on people's welfare by cutting key social spending lines after 1929. Brüning was commonly known as the 'Hunger Chancellor', stressing how these budget cuts threatened living conditions. There is in fact some qualitative consensus on Brüning's devastating legacy. Feinstein et al. (2008: 90) opine that "Brüning introduced a succession of austerity decrees. The descent was cumulative and catastrophic." Several authors also noted that austerity could have contributed to political extremism. For instance, Feldman (2005: 494) comments that "Brüning's reliance on emergency decrees had paved the way for a right-wing rule" and Eichengreen (2015: 139) that "Brüning's unrelenting austerity, by plunging the economy deeper into recession, increased political polarization".

Hitler also viewed austerity as a springboard to power. Twelve days after Brüning enacted his fourth and last emergency decree, Hitler issued a mass pamphlet titled The Great Illusion of the Last Emergency Decree. He concluded the letter saying that "Although that was not the intention, this emergency decree will help my party to victory, and therefore put an end to the illusions of the present system". There are also attacks on Brüning's cabinet on

\footnotetext{
${ }^{1}$ Other explanations invoke the Weimar Republic's electoral system, where each party was allotted a number of seats in the Reichstag proportional to the votes received, which cleared the path for small parties to enter the Reichstag (Jepsen 1953). Historians also stress the animosity between the two major parties of the left and difficulties in building lasting coalitions. However, Evans (2003) notes that proportional representation did not, in fact, encourage the rise of the extreme right, and alternative electoral systems might have given the Nazi party even more seats.
} 
earlier fiscal plans. For instance, in October 1931 Hitler wrote an Open letter from Adolf Hitler to the Reich Chancellor in which he asked "where has the hereby-reduced number of unemployed been left? Where are the successes of the 'rescue of agriculture'? And when, Mister Chancellor Brüning, did the then-promised reduction of taxes finally begin?"

These pamphlets also made promises to relax the budget constraint if the Nazis were elected. For instance, on May 1932 a pamphlet titled Emergency Economic Program of the NSDAP offered "fundamental improvements in agriculture in general, multiple years of taxation exemption for the settlers, cheap loans and the creation of markets by improving transportation routes, and making them less expensive." On the welfare system, "National Socialism will do all it can to maintain the social insurance system, which has been driven to collapse by the present System."22.

\section{Austerity and the German elections}

Before delving into the implications of austerity on the Nazi electoral success, it is first necessary to review how austerity was implemented and the context of each election. Brüning was appointed as German Chancellor by President von Hindenburg in March 1930 and fiscal reforms were quickly implemented, with a first austerity plan in July 1930. Austerity was implemented by emergency decree under the article 48 of the constitution, with the Reichstag eventually consenting without formal debate. From its beginning, austerity was highly unpopular, leading von Hindenburg to dissolve the Reichstag and call new elections $!^{3}$

In the elections of September 1930, the Social Democratic Party (SPD), the political home of the worker movement, remained as the largest party in the Reichstag (yet, moving

\footnotetext{
${ }^{2}$ There is also evidence that austerity formed part of Goebbels' propaganda machine. For instance, in a speech in 2 May 1931 at the Reichstag, Goebbels very prominently also alluded to tax pressure on the middle-class (Goebbels 1931). We thank Hans-Joachim Voth for calling this speech to our attention.

${ }^{3}$ As Eichengreen (2018: 86) notes, "that the most dramatic cuts were imposed by decree, circumventing normal legislative deliberation, did not foster popular admiration of the politicians then in office or enhance the legitimacy of the constitutional system."
} 
from 29.8 percent of the total votes in May 1928 to 24.5 percent in 1930). The Center party, which was Brüning's party, also started to lose popularity (moving from 12.1 to 11.8 percent), and the Communist party, the main party of protest for those workers disenchanted by the Weimar regime, managed to collect new votes (moving from 10.6 to 13.1 percent). The German National People's Party (DNVP), a bourgeois, xenophobe and far-right party that shared many of the Nazi's extremist views, declined from 14.2 percent of total votes to 7 percent. Above all these changes, support to the Nazi party surged from almost no support to more than 6 million voters (moving from less than 3 percent to 18.3 percent).

Despite austerity was only implemented some months in advance, the September 1930 election was a key turning point in German history, because it was seen as a withering verdict against austerity-a message that went unheeded. As discussed by Temin (1990: 82) "... it is clear that the vote of 1930 was a resounding rejection of Brüning's policies at an early stage." Initially, only the Nazis (and to some extent the Communists) campaigned against austerity, with the DNVP struggling to find a coherent response on the austerity front. For instance, Fulda (2009: 158) reviews that for the first emergency decree, "the parliamentary DNVP was split: while Hugenberg's followers voted against it, the group around Westarp decided to support it." He also comments that when "the tension between the pro-Brüning DNVP parliamentarians around Westarp and Hugenberg's supporters increased... Goebbels noted in his diary that the DNVP was 'finished': 'All grist to our mill." 4 As for the SPD, Brüning's memoirs highlight that he often turned to members of the SPD for support. Successive emergency decrees in June 1931, October 1931 and December 1931 raised nearly all of the main taxes controlled by the Reich (income, wage, turnover, excise duties, tariffs), put limits to spending and exclusions from unemployment and relief benefits, and mandated civil service pay cuts (over 50 percent of the state level spending bill according to Balderston (1993)).

\footnotetext{
${ }^{4}$ By July 1930, the DNVP was split in two parties, with Westarp's followers founding the Konservative Volkspartei (supporting Brüning's government), and the rest commanded by Hugenberg, radicalized and tried to approach the Nazi party.
} 
By the end of May 1932, Brüning was removed from the Chancellorship and was replaced by von Papen. The elections of July 1932 boosted Nazi popularity even more, achieving 37.3 percent of the votes. Yet, the Nazis lacked an overall majority at the Reichstag and von Papen continued as Chancellor. In the second half of 1932, von Papen signaled the end of austerity and started to introduce some stimulus packages, involving employment programs, tax credits and subsidies for new employment and public works projects (Evans 2003; Feinstein et al. 2008). Despite any short-lived effect was modest in magnitude compared to the cumulative effect of Brüning's austerity, the easing of austerity, along with the ostensible cancellation of War debts at the Lausanne conference and an improved economic environment 5 coincided with a decline in Nazi vote share in the elections of November 1932 (collecting 33.1 percent of the votes). As O'Rourke (2010) comments, "by this stage Brüning was gone, his successor adopted some modestly stimulative policies, and there were signs of a partial recovery. Not coincidentally, in November 1932 the Nazi share dipped to 33.1 percent; but by then it was too late, and the Weimar Republic was doomed."

von Papen had virtually no support in the Reichstag, and in an ill-attempt to increase his support, he called for new elections in November of 1932. Yet, given mass discontent and social instabilities, later on Hindenburg appointed Schleicher of the DNVP as Chancellor ${ }^{6}$ He lasted for less than two months. Adolf Hitler was appointed chancellor on 30 January ahead of the decisive elections of March 1933 where the Nazi party became the largest party (with 44 percent of the votes) and built a bare working majority with the DNVP that offered 8 percent of the votes.7 These were the last elections of the Weimar Republic, and were tarnished by violence and intimidation and might not be regarded as free and democratic.

Under Brüning's mandate, there was a process of centralizing the fiscal policy and the national government began to limit the ability of states to raise tax rates as well as limit

\footnotetext{
${ }^{5}$ Between 1932 and 1933 real GDP grew by 6 percent. By comparison, real GDP fell by 8 percent between 1931 and 1932 .

${ }^{6}$ Schleicher also introduced some public works programs.

${ }^{7}$ In the elections of 1933 , the DNVP presented in the elections as part of a coalition, the Kampffront Schwarz-Weiß-Rot, which was an electoral alliance of three parties: the DNVP, the Stahlhelm and Landbund.
} 
federal authority spending (Balderston 1993) ${ }^{8}$ James (1986: 76) also commented that regional governments were "left with odious taxes and falling revenues." Although austerity was determined at the Reich level, the extent to which it mattered varied regionally. This variation depended on how lower levels of government allocated their revenue to different types of expenditure and what the sources of their tax revenues were. Around 40 percent of the spending cuts were implemented by local authorities, mainly municipalities and the so-called administrative divisions (Regierungsbezirke), 22 percent by the different states and around one third by the Reich (Newcomer 1936). Hence, the impact of Reich mandated cuts on the states varied according to a number of pre-determined fixed factors, including population and land area, number of schools, highway mileage, and the distribution of income (Newcomer 1936: 205).9

Political affinity to Brüning's policies might have mattered, but in essence, spending cuts were mandated at the central level. The room for maneuver in the states was also highly constrained. States could no longer borrow on international capital markets after 1930 and only a small share of state spending was accounted for by local tax revenue over which a state had control. While local politicians could potentially shift spending between categories, the Reich increasingly dictated the way in which states should spend money, put caps on spending categories, and in many instances, they relied heavily on targeted Reich subsidies or transfers. States were thus also constrained both by an inability to legislate tax rates, and by the traditional ways of re-distributing tax revenue. Our bottom line is that responding to the recession with discretionary spending was not much of a possibility and both income

\footnotetext{
${ }^{8}$ There were two main bases for collection and re-distributing revenue: origin and population. While the origin base (returning revenue to the locality where it was collected) failed to take into account the local need factor, redistribution by the population principle could be effective in terms of 'need'. Yet, the extent of re-distribution depended on state political bargains and most of the taxes in question were distributed on origin basis (Wueller 1933: 38).

${ }^{9}$ It is possible that greater unemployment also generated greater transfers via the unemployment insurance scheme. Yet, by 1931, the period of eligibility for unemployment relief was drastically restricted and nearly all people under 21 years were excluded from welfare benefits. These measures were offset by the end of 1931 somewhat with greater relief payments and a partial rollback of the exclusion (Balderston 1993).
} 
$\operatorname{tax}[10$ and expenditure were largely out of the hands of state governments and local authorities 11

\section{Data}

We collected data from official German sources (see our Data Appendix for details). Our analysis begins by measuring the impact of austerity on electoral outcomes at the citylevel. Data on electoral returns for the Reichstag elections are from the official publication Statistik des Deutschen Reiches (volumes Wahlem zum Reichstag), with all the other data at the city-level coming from the Statistisches Jahrbuch Deutscher Städte, which report data for cities above 50,000 inhabitants $(n=98)$. For each city, we collected city spending data for each fiscal year from 1929/30 to 1932/33 which includes transfers from higher levels of government and spending by budget category, in 1,000 RM. Such detailed data at city-level allow us to look at the type of spending and the potential mechanisms by which spending changes can affect electoral outcomes. The fiscal years ran from 1 April to 31 March and when we say 1929 this refers to the fiscal year 1929/30. We also collected data from the federal transfers to cities (a variable called Überweisungen aus Reichsteuern) to construct a Bartik-style instrument as discussed below.

To test competing explanations, we further used data on city level unemployment. Unemployment is defined as the number of people in the labor force not working and registered in the local offices as unemployed. We proxy city economic conditions by the construction of new residential apartment buildings. We also collected mortality data from the bulletins of the Reichs-Gesundheitsblatt. These bulletins report detailed mortality data at the weekly level for cities with a population larger than 100,000 inhabitants $(n=51)$.

\footnotetext{
${ }^{10}$ Income tax was a key tax in the Weimar revenue system (with 20 percent of total revenue).

${ }^{11}$ Here Newcomer (1936: 205) comments that "it is unfortunate that the equalizing factors adopted have been vitiated in a number of instances by guarantees of pre-war income." See also Wueller (1933: 36).
} 
We also study district (kreis) level data $(n=1,024)$, where data on taxes, but not spending are available. Electoral and fiscal data on taxes are from the official Statistik des Deutschen Reiches ${ }^{12}$ For taxes, we collected data on the number of taxpayers, total taxable income, and total revenue for each state (in 1,000 RM) on two main federally administered income taxes: the lohnsteuer, a withholding tax deducted at source and the einkommenssteuer, an ex-post income declaration tax only paid by middle and high rate payers. For the 'wage tax' (lohnsteuer), data are available in 1928/29 and 1932/33, and for the 'income tax' (einkommenssteuer) for the years 1928/29, 1929/30, and 1932/33 (see also Dell 2007). Despite missing data for some years, the available years allow us to capture the main changes in taxation in the period of interest (September 1930 to March 1933), and rather than having highly temporally disaggregated data, we rely on benchmark years under the assumption that the impact of austerity is cumulative. We also collected state-level data on taxes (the lohnsteuer and einkommenssteuer) for the same years as in the district sample ${ }^{13}$

From the statistical abstracts Statistisches Jahrbuch für das Deutsche Reich, we collected state-level data on spending, unemployment (number of people in the labor force not working), an index of hourly wages ${ }^{14}$ and a proxy economic output (generation of electricity, in $1,000 \mathrm{kWh})$. For the latter one, we use a proxy based on electricity generation, as these two correlate closely, since the vast majority of goods and services are produced using electricity. Other district-level data used in the data appendix, such as the number of welfare recipients, are from Statistik des Deutschen Reiches (volume Die Öffentliche Fürsorge im Deutschen Reich). Table A1 reports the main summary statistics on key variables.

On the magnitude of austerity, as Figure 1 shows, between 1930 and 1932 state level real expenditure was cut by 8 percent (nominal total spending fell by about 25 percent)

\footnotetext{
${ }^{12}$ In the Data Appendix, we show the spatial distribution of district-level income taxes.

${ }^{13}$ For simplicity, when we say States, we also mean Prussian Provinces.

${ }^{14}$ We created a state-level index of nominal wages averaging the monthly data from the hourly wages paid in four occupations (construction, wood and skilled and unskilled workers in metallurgy) in 38 big cities which have been located within each of the states.
} 
and Reich level real expenditure fell by 14 percent (30 percent nominal) 15 These were not insignificant components of aggregate demand since together, state and Reich expenditure totaled close to 30 percent of GDP in 1928/29.

[Figure 1 about here]

\section{Nazi support and City-level spending}

With the launch of austerity in July 1930, the number of votes for the Nazi party soared from 6 million to 14 million between the elections of September 1930 and July 1932. Indeed, as Figure 2 suggest, there is a close negative association between the increase in the Nazi vote share between September 1930 and July 1932 and the change in city-level spending between 1929/30 and 1930/31. We next explore these issues more rigorously and implement some empirical strategies to limit biases due to endogeneity.

[Figure 2 about here]

\subsection{Results}

We begin our analysis reporting the results of statistical models where the dependent variable is the level of the Nazi vote share across cities in federal elections. We use city fixed effects throughout so that we rely on within city variation to identify of the impact of austerity on Nazi vote share. With these specifications, our models yield a difference-in-differences with an intensity of treatment interpretation based on:

$\mathrm{NAZI}_{c t}=\alpha+\beta_{1} \ln \left(\right.$ Expenditures $\left._{c t}\right)+\beta_{2} \ln \left(\right.$ Unemployment $\left._{c t}\right)+\beta_{3} \ln \left(\right.$ Output $\left._{c t}\right)+\mu_{c}+\delta_{t}+\varepsilon_{c t}$

where $c$ is a city, $t$ is a calendar year, and NAZI denotes the vote share of the Nazi party as measured by the ratio of the number of votes to the Nazi party over the total

\footnotetext{
${ }^{15}$ The spending data includes transfers to other public authorities.
} 
number of (valid) votes cast. Expenditures $c$ comprise all categories of city expenditure, Unemployment $_{c t}$ is the number of registered unemployed in a city, Output $t_{c t}$ is our proxy for economic output in a city and $\varepsilon_{c t}$ is an error term. These control variables are expressed in natural logarithms ${ }^{16}$ We standardize data to have a mean of zero and a standard deviation of one, so coefficients across models are directly comparable. We also include city fixed effects $\left(\mu_{c}\right)$ and fixed effects for the calendar years of 1932 and $1933\left(\delta_{t}\right)$. We report standard errors clustered at the administrative division level. There are 44 clusters and by clustering at the administrative division (above the city-level), we allow for arbitrary correlations of the error term within the cluster. Additionally, many of the variables were decided above the city-level and fixed effects already pick up city-level correlations. ${ }^{17}$

In Table 1 (column 2) we show that a one standard deviation increase in the natural logarithm of spending is associated with a decrease in Nazi vote share (in standard deviation terms) by from -0.42 (95\% CI: -0.68 to -0.15$)$. This specification, which pools data for the four elections between 1930 and 1933, is robust to the inclusion of administrative division or state by period fixed effects (columns 3 and 4) 18 These lasts specifications control for time-varying unobservable shocks or arbitrary unobserved trends at administrative division or state level. Since shocks are likely to be highly spatially correlated, these controls mop up the effect of spending changes after controlling for local economic and political shocks.

This table also displays the results for other competing explanations for the rise of the Nazi party. Despite the fact that the coefficient on unemployment typically shows a positive sign, it is only statistically significant in column 4. As Ferguson (1997: 267) notes, this is

\footnotetext{
${ }^{16}$ We use the values of city-level government spending for fiscal year 1929/30 for the elections of September 1930, values for 1931/32 for the elections of July and November 1932 and values of 1932/33 for the election of 1933

${ }^{17}$ As a robustness check, throughout the paper, we also explored clustering at the city- and state-level (unreported here), and found that spatial dependence is not a major concern in our data. For a similar finding see Satyanath et al. 2017, footnote 22.

${ }^{18}$ Specifically, we interact state fixed effects with a second period (1932) for the sample using 1930 and 1932 elections. For the sample that includes all elections we interact state and administrative division level fixed effects with an indicator for each year 1932 and 1933.
} 
a likely outcome, as "it is a popular misconception that because high unemployment coincided with rising Nazi support, the unemployed must have voted for Hitler. Although some did, unemployed workers were more likely to turn to Communism than to Nazism." When controlling for austerity and unemployment, in most cases the economic output variable is also not statistically significantly.

[Table 1 about here]

We next modify the outcome variable to be the vote share among other parties. This change allows us to see how austerity affected the rest of the German political spectrum. To also show that our results are not driven by a single election (or group of elections), we provide the results in three separate forest plots pooling data for the elections of 1930 and 1933; elections of 1930 and 1932 (both elections); and the four elections between 1930 and 1933.

Results for the Nazi party in Figure 3 show that there is a negative and statistically significantly association between spending and the Nazi party vote share in the different elections between 1930 and 1933. Results for the other parties, suggest that austerity mostly drew votes from the Center party. This is not surprising as the Center party was Brüning's party and the party became very unpopular for consolidating the budget. For instance, Straumann (2019: 207) comments that "the harsh austerity measures of December 1931... pushed the popularity of the Brüning cabinet down to a new low." Results also display a positive sign for the SPD (although not always statistically significant), and the Communist party (when avoiding the violent elections of 1933). Results for the DNVP highlight their lack of political position on the austerity front.

[Figure 3 about here] 


\subsection{Robustness checks}

In Table A2 we also pool all elections and study the dynamics of the effects via interaction terms. Specifically, we interacted the spending data with a dummy for each election so we estimated 3 coefficients: 7/1932, 11/1932 and 1/1933 and then one for austerity uninteracted which corresponds to the 'omitted' category which is 1930. In this way, we show that the austerity effect is stable across time, as the sample is kept stable and the reference point still remains 1930. We further test for the validity of our estimates in different ways.19 For instance, in Table A3, we divided each of the right-hand side variables by population to show that our fixed effects models are very likely to proxy for a stable population over the short horizon between 1930 and 1933. Table A4 further explores the interaction of the shock of the Depression with social structure. We interacted year fixed effects with the share of blue-collar workers in 1925 and the share of the population identifying as Catholic or Protestant ${ }^{20}$ The time interactions on religious identity are significant, suggesting a role for such interaction. However, austerity mattered in a similar way in Catholic and Protestant areas, though the impact is higher in places with a Jewish community. ${ }^{21}$

\footnotetext{
${ }^{19}$ We also used the data on the city number of entries to the Nazi party from Satyanath et al. (2017) and explored the impact of austerity on joining the Nazi party. Specifically, we use the log of the number of entries in the Nazi party in the preceding year and we focus on the inflow of people into the party rather than on the stock of party members. Using a specification equivalent to equation (1) and pooling data from 1931-1933, the results strengthen the case that nationalist and racist ideals (Shirer 1960), became more salient when compounded by austerity, driving people towards the Nazi ideology.

${ }^{20}$ Using equation (1), we also split the sample for Prussian and non-Prussian cities and found that in both cases results are negative and statistically significant, with point estimates being larger in Prussian cities.

${ }^{21}$ In Table A5 we also show that results hold when we control for the severity of the depression using data on the number of welfare recipients. While this variable might be colinear with spending, not controlling for spending but for the number of recipients suggests that expectations might also have mattered. People could also respond to perceived austerity rather than actual exposure to austerity.
} 


\subsection{IV and Endogeneity}

One may worry that changes in spending were choice variables reflecting the (unobservable) state of the underlying economy or the level of local political competition. Politicians could alter spending levels in response to these and their perceptions of these and other variables making it problematic to infer the impact of exogenous changes in spending on votes for an extreme party like the Nazis. To deal with the potential endogeneity of expenditures, we employ a shift share instrumental variable in the spirit of Aizer (2010) which relies on variation at the national in "across-the-board" cuts imposed by Brüning. Consider the following stylized equation for total government spending $G$ in city $c$ in fiscal year $t$ :

$$
G_{c t}=G_{F c t}+G_{L c t}
$$

Spending in city $c$ is composed of two components. One is federal transfers or the federally mandated level of spending $G_{F c t}$. This variable could also be construed as local spending based on local claims to federal revenue streams where the subscript $F$ denotes federal transfers or mandates to city $c$. The other component, $\mathrm{G}_{L c t}$, is based on local decision making and local revenues. Assuming that this spending is constant, then the change in total spending between period $t$ and period $t-1$ given an $(\alpha-1)$ percent change in federal spending applied to all localities $(0 \leq \alpha \leq 1)$ is given by:

$$
\% \Delta G_{c t}=\frac{G_{F c t-1}}{G_{c t-1}}(\alpha-1)
$$

The absolute value of the percentage change in spending is directly related to the share of federal spending in total city spending. That is, the larger the share of $\mathrm{G}_{F c t-1}$ in $\mathrm{G}_{c t-1}$, the larger the percentage fall in total spending, $\left(\% \Delta G_{c t}\right)$ for a $(\alpha-1) \%$ change in $\mathrm{G}_{F c t-1}$. Our instrument is therefore the initial share of federal transfers in total city spending in 1929 interacted with year indicators represented by $\delta_{t}$ which themselves proxy for the "acrossthe-board" nationally imposed spending cuts. This two-stage least squares approach is reminiscent of Nakamura and Steinsson (2014) or Chodorow-Reich et al. (2012). 
To satisfy exogeneity we assume that $\mathrm{E}\left[\left(\frac{G_{F C 1929}}{G_{C 1929}} \delta_{t}\right) \mathrm{e}_{c t}\right]=0$. In a broader survey on shiftshare instruments, Goldsmith-Pinkham et al. (2020) argue that if initial shares $\left(\frac{G_{F C 1929}}{G_{C 1929}}\right)$ are exogenous, the Bartik-style or shift-share instrument boils down to using initial shares (interacted with time dummies) as excluded instruments. With two sectors they also show it is only necessary to use one sector share and this is equivalent to a Bartik approach. To satisfy the exclusion restriction, one would have to believe that reliance on the central government in 1928 was not related to the unobservables driving the change in Nazi vote share. As suggested by Goldsmith-Pinkham et al. (2020), we tested this by regressing the initial share on observables such as the share of Protestants and Catholics, levels of unemployment or the construction of new buildings. In none of the cases were these variables statistically significant. For relevance, the log deviation in spending from the within city mean must be correlated with the initial dependency on the Reich transfers. This would evidently be true unless local spending changes completely offset (orthogonal) Reich spending changes. This is not possible since localities could not fund spending by borrowing due to financial market dislocation and due to the fact that total tax revenue was falling due to the decline in aggregate activity.

As Table 2 shows, using OLS the impact in terms of standard deviations in vote share for the Nazi party associated with a one standard deviation increase in the percentage change in spending is -0.78 (95\% CI: -1.21 to -0.34) in the elections of 1930 and 1932 (both) and -0.55 (95\% CI: -0.77 to -0.34$)$ when considering all elections ${ }^{22}$ Results using 2SLS are just $15 \%$ larger (in absolute magnitude) than the OLS results in column 4, showing that OLS results may not be highly biased. In Table A6 we also show the Bartik results using models in differences.

[Table 2 about here]

\footnotetext{
${ }^{22}$ We also checked for linearity categorizing the spending data into bins and including the dummy variables for the bins in the model. We also explored this with bins of different sizes in the spending data. The assumption of linearity is largely suitable.
} 


\subsection{Mechanisms}

In Figure 4 we modified equation (1) and, instead of all city level expenditure, we study the impact of changes in different types of expenditure. Interestingly, most of the effect of austerity is driven by spending changes in health and wellbeing (-1.03: 95\% CI: -1.53 to -0.52$)$ and housing (-0.21: $95 \%$ CI: -0.39 to -0.03$)$. These were among the budgets most affected by austerity ${ }^{23}$ The size of the effect for spending changes in health and wellbeing are $32 \%$ higher than the overall effects of the spending changes presented in the previous table, showing that social spending changes plausibly exacerbated the suffering of the German masses. There is also a positive effect of expenditure in construction and the Nazi vote share between the elections of September 1930 and 1933. As we have already seen, by the end of 1932 von Papen and Schleicher introduced some tax discounts, construction and works programs, along with Hitler's promise to construct an autobahn symbols of a new era of economic competence and end of austerity (Voigtländer and Voth 2019). However, the effect disappears when we introduce data for the austerity years and the elections of 1932.

[Figure 4 about here]

The literature also stresses that Brüning's fiscal plans were part of a political strategy to elicit international sympathy for German suffering putting an end to WW1 reparations. ${ }^{24}$ Coinciding with the fiscal retrenchment, mortality rates, which had been declining, started to rise rapidly after 1932. One mechanism for the rise of populist parties is that they gain the most votes where health fares worst. This link was outlined by some commentators at the time. For instance, by the fall of October 1930, Hjalmar Schacht (former head of the Reichsbank) gave an interview to the American Press saying that "If the German people are

\footnotetext{
${ }^{23}$ As noted by Straumann (2019: 70) on the Second Emergency Decree, "the plan proposed a series of spending cuts, notably of health insurance compensations and of revenues apportioned to states and municipalities."

${ }^{24}$ This strategy, was never a clear political winner, and soon it lacked an economic rationale. By June 1931, the Hoover Moratorium had suspended Germany's WW1 debts for one year. A year later, in July 1932, reparations were permanently postponed at the Lausanne Conference.
} 
going to starve, there are going to be many more Hitlers" (The New York Times, 3 October 1930).

Next, we report suggestive evidence that the effect of spending cuts was through the channel of higher mortality. In Table 3 we used equation (1) and also add a control for mortality. Since we use city fixed effects, mortality here can be interpreted as excess mortality, that is within city changes or deviations of mortality from its within sample mean. Instead of overall spending, we use only spending in health and wellbeing. Column 1 shows that after controlling for unemployment and economic output and other fixed effects, increases in spending are negatively and statistically related to Nazi party vote. Similarly, column 2 shows that, without controlling for spending, higher mortality is associated with higher Nazi vote share. However, once we add the mortality control (column 3), expenditure is no longer statistically significant and the size of the coefficient declines by 34 percent. If we remove the deaths from cancers and a category for ill-defined causes, the coefficient for mortality remains statistically significant at 1 percent level of confidence (column 5), but the coefficient on spending declines by more than half, and it is not statistically significant. Although results are weaker for infant mortality, possibly because as others have noted, births to the poorest families fall disproportionately during a recession (Dehejia and Lleras-Muney 2004), they display a low p-value (column 7). This result further illustrates that the impact of austerity was potentially channeled through suffering (as measured by changes in mortality). It is also interesting that the coefficients on unemployment and economic output once we control for austerity are similar before and after we include the mortality control.

[Table 3 about here] 


\section{Nazi support and district-level taxes}

\subsection{Results}

We next move to district-level data. Since spending data at the district level are unavailable from national sources, we rely on within district variation in income taxes as our measure of austerity. We assume that for an individual voter, changes in taxes have an impact analogous, if not proportional, to cuts in spending. Both fiscal variables would presumably have an economic and potentially psychic impact on the well-being, and political preferences of an individual voter. Changes in tax rates would alter an agent's budget constraint and choices much the same as a direct change in income due to modifications of targeted transfers or other government spending on services. Alternatively, utility derived from public good flows could also be altered to the extent that public goods are a function of spending or the revenue that is necessary to finance such spending.

We model the impact of austerity on Nazi vote share using the following equation:

$\operatorname{NAZI}_{d t}=\beta_{1} \ln \left(\right.$ Tax Rate $\left.(\rho)_{d t}\right)+\beta_{2} \ln \left(\right.$ Wages $\left._{s t}\right)+\beta_{3} \ln \left(\right.$ Unemployment $\left._{s t}\right)+\beta_{4} \ln \left(\right.$ Output $\left._{s t}\right)+$ $\mu_{d}+\delta_{t}+\varepsilon_{d t}$

where the average Tax Rate (either the average rate of income or wage taxes and denoted by $\rho$ ) is calculated as the ratio of tax revenue divided by total declared taxable income. Tax rates are indexed by districts $d$, other controls by states, $s$, and $t$ is an election period (September 1930, July 1932, November 1932 or March 1933). Since we do not have annual data on taxes, we linked the income taxes for the fiscal year 1929/30 to the elections of September 1930 and the taxes for the fiscal year 1932/33 to the elections of 1932 and 1933. Since wage taxes are unavailable for the fiscal year 1929/30, we had to link the wage taxes for 1928/29 to the elections of 1930 and the taxes for 1932/33 to the elections of 1932 and 1933. NAZI denotes the percentage point vote share of the Nazi party in the four different federal elections. We also include district fixed effects $\left(\mu_{d}\right)$ and a fixed effect for the fiscal year 1932/33 $\left(\delta_{t}\right)$ and report standard errors clustered at the district and state level. 
The results in Table 4 (column 1) show that the impact in terms of standard deviations in vote share for the Nazi party associated with a one standard deviation rise in the natural logarithm of the average tax rate is 0.16 using income taxes (95\% CI: 0.78 to 0.25 ) and 0.19 using wage taxes (95\% CI: 0.09 to 0.30 ). This result suggests that the Nazi party received more votes in districts with great austerity whether austerity is measured as cuts in government spending or rises in the tax rate.

To control for endogeneity, we also instrumented the tax rate with the level of the average income tax rate in 1928 (column 7) interacted with time dummies. The percentage change in the average income tax rate $T$ is the weighted average of statutory rates with the weights equal to the share of total taxable income within each tax bracket. Assuming constant shares, the observed percentage change in the average tax rate, denoted by $\widehat{T}$ for district $d$ in period $t$ is given by:

$$
\widehat{T}_{d t}=\sum_{b} \omega_{d b} \widehat{\tau}_{b t}
$$

where the weights, $\omega_{d b}$, are the ratio of total taxable income in bracket, $b$, to total taxable income across all brackets in an initial year and $\tau_{b t}$ are the nationally defined statuory tax rates for each bracket.

In 1930, under austerity, statutory income tax rates for each bracket were raised equally nationwide. The change in the average depends on the initial shares. As Pinkham-Goldsmith et al. (2018) show, the relevant Bartik-style instrument for this national shock to tax rates with $b$ shares and one time period is equivalent to using the initial shares as instruments. The average income tax rate in 1928 is again, the sum of these shares (at the district level) with each share being multiplied by the same constant, $\tau_{b 1928}$ (the 1928 statutory tax rate) across all districts. We use this initial value (interacted with period fixed effects) as the excluded instruments. The first stage coefficient on the excluded instrument, the initial average income tax rate, is negative and statistically significant. The negative sign is due to the fact that the statutory tax rates rose more in proportional terms for the lowest tax brackets than the higher tax brackets. 
Using the initial average income tax rate as an excluded instrument, we find a positive relationship between changes in tax rates and Nazi vote share (column 7). Results are not dependent on clustering at the district level or at the state level. Nevertheless, the size of the standardized coefficients using the IV are between two and three times larger those using OLS and since wage taxes were unavailable for 1929/30 we cannot use this instrument for wage taxes. There is no obvious reason why the point estimate on taxes using the IV approach are so much larger than in OLS. However, there is a possibility of some heterogeneity in the impact of tax rises such that the nationally imposed tax changes had a much larger impact in certain kinds of districts.

In Table A7 we also use a differenced model. We further show that results are robust to the addition of state fixed effects, which allows for differential state-level trends and potentially mops up some of the within state correlations in the error term. ${ }^{25}$ In column 4 we weight the regressions by the level of population to emphasize the data from the larger districts and states and eliminate undue influence from smaller states. In columns 5 and 6 we also add the lagged Nazi vote share to control for differential growth based on initial Nazi support in 1930. Lagged values refer to the election immediately prior to the latest election in the differenced dependent variable. Again, results are also very stable across specifications.

In Table A8 we explore potential heterogeneity in the impact of austerity. Here we split the sample for values above and below the median vote share for the Nazi party in the elections of 1928 and the median values for the share of the labor force in agriculture, industry, in civil service, those self-employed and in blue collar occupations using the census data of 1925. When we stratify the sample, we show that rather than electoral tax rise, the impact of austerity had a larger effect in pre-1930 Nazi strongholds, districts with a low share of blue-collar workers, in rural, agricultural and less industrialized areas, with a higher share of civil servants and self-employed workers. It seems that austerity was a bigger determinant for those living in small towns or the country-side and those who were self-employed, rather

\footnotetext{
${ }^{25}$ Results for income $(0.13 ; 95 \%$ CI: 0.07 to 0.19$)$ and wage taxes $(0.09 ; 95 \%$ CI: 0.04 to 0.15$)$ are also statistically significant at 1 percent level of confidence using administrative division fixed effects.
} 
than residents of the largest cities who were more likely to become unemployed, who turned to the Communists.

\section{[Table 4 about here]}

\subsection{Robustness checks}

We pursued a number of additional robustness checks. In Figure A1 we drop one state at a time to show that our results are not driven by a particular state. In Table A9, we also study the impact of taxes on the vote shares for the main political parties. Additionally, in Table A10, we use first differences to calculate the taxes as the percentage point change (the change in the level) instead of the percentage change in average income and wage tax rates.

For another robustness check we use a policy discontinuity design at state borders a method which uses a potentially more relevant set of control groups. ${ }^{26}$ For each election at date $t$ ( $t$ defined by the elections of September 1930 and July 1932), our border district pairs data are organized to have at least two observations in each pair $p$ (one for each state in the pair). A given district appears in the data $k$ times (for each election $t$ ) if it borders $k$ districts. In total there are 459 districts that lie along a state border and for each border-district we match all the neighboring districts that are located on opposite sides of the borders, yielding a total of 1,080 border-pairs. ${ }^{27}$ The district-pair match on the opposite side of a state border is a plausible control group since while there are substantial differences in treatment intensity of austerity, due to differing state level policies and initial conditions, these pairs, are very similar politically and economically and approaching the border, most controls vary smoothly, but the treatment variable jumps (Table A11). Hence, variation in austerity at the district level across state borders would be due to differences in state level decisions on austerity.

\footnotetext{
${ }^{26}$ For a review of this methodology see Dube et al. (2010), Holmes (1998) and Galofré-Vilà (2020).

${ }^{27}$ Missing data reduces somewhat the sample size from these numbers.
} 
Our difference-in-differences specification is as follows:

$\Delta \mathrm{NAZI}_{d t}=\alpha+\beta_{1} \ln$ Surplus $(\rho)_{s t}+\beta_{2} \ln$ Wages $_{s t}+\beta_{3} \ln \mathrm{Unemployment}_{s t}+\beta_{4} \ln$ Output $_{s t}+$ $\mu_{p / p t}+\delta_{t}+\varepsilon_{d t}$

where NAZI denotes the Nazi party vote share in district $d$ in year $t$. To unite spending and taxes in the same equation, we measure austerity as the fiscal Surplus: the logarithm of the total state income taxes paid minus the logarithm of state-level expenditure. We use income and wage taxes in alternative specifications indexed by $\rho$. Using a higher level of aggregation than the district for spending and taxes makes variation in treatment more plausible since state changes are determined by within state factors. Additionally, spending data are only available at the state level. Along with the standard controls as in previous equations, we use district $\left(\mu_{d}\right)$, time fixed effects $\left(\delta_{t}\right)$ or district pair by year effects, and cluster the standard errors at the state level. This level of clustering also accounts for potential mechanical spatial correlations given the presence of districts in multiple pairs. In Table 5 we provide four types of specifications according to whether we use district-pair fixed effects $\left(\mu_{p}\right)$ and district-pair fixed effects by year interactions $\left(\mu_{p t}\right)$.

We find that the variable Surplus for the border pair sample is also positive and statistically significant using the two-way clustering or with very low p-values. For instance, a time-varying district-pair fixed effects model using Surplus 1 gives a standardized coefficient of 0.28 (95\% CI: 0.15 to 0.42 ) and using Surplus 2 a coefficient of 0.23 (95\% CI: 0.06 to 0.40). This well-identified piece of variation, comparing neighboring districts that straddle state borders, produces consistent results with the full sample. In Table A12 we also obtain consistent results by instrumenting the percentage change in the average tax rate with the initial level of taxes paid in 1928 using district-pair and state level clustering along with district pair fixed effects.

[Table 5 about here] 


\section{Conclusions}

This paper offers econometric support for the idea that the austerity measures implemented between 1930 and 1932 immiserized and radicalized the German electorate. Each one standard deviation increase in austerity measured in several different ways was associated with between one quarter to one half of one standard deviation of the dependent variable. Yet, austerity is only one factor affecting the rise of the Nazi party and there are other factors at work such as the role of German business (Ferguson and Voth 2008), the historical roots of antisemitism (Voigtländer and Voth 2012), the influence of social capital (Satyanath et al. 2017), banking collapse (Doerr et al. 2018), and the power of radio propaganda (Adena et al. 2015). For a recent review see Voth (2020).

Austerity worsened the situation of low-income households and the Nazi party become very efficient in channeling the austerity-driven German suffering and mass discontent. We exploit this mechanism by showing that austerity was associated with higher mortality. This reinforces the idea that, had Brüning relaxed the efforts to consolidate the budget, things might have been different.

The corollary seems clear: even when the particular history of a country precludes a populist extreme-right option, austerity policies are likely to produce an intense rejection of the established political parties, with the subsequent dramatic alteration of the political order. The case of Weimar Germany explored in this article provides a timely example that imposing too much austerity and too many punitive conditions can not only be self-defeating, but can also unleash a series of unintended political consequences, with truly unpredictable and potentially tragic results. 


\section{References}

Adena, Maja, Ruben Enikolopov, Maria Petrova, Veronica Santarosa, and Ekaterina Zhuravskaya. "Radio and the Rise of the Nazis in Prewar Germany." The Quarterly Journal of Economics 130 no. 4 (2015): 1885-1939.

Aizer, Anna. "The Gender Wage Gap and Domestic Violence." American Economic Review 100 no. 4 (2010): 1847-59.

Alesiana, Alberto, Carlo Favero, and Francesco Giavazzi. Austerity: When it Works and When It Doesn't. Princeton University Press, 2019.

Balderston, Theo. The Origins and Course of the German Economic Crisis, November 1923 to May 1932. Haude and Spener, 1993.

Bor, Jacob. "Diverging Life Expectancies and Voting Patterns in the 2016 US Presidential Election." American Journal of Public Health 107 no. 10 (2017), 1560-62.

Borchardt, Knut. "Wirtschaftliche Ursachen des Scheiterns der Weimarer Republik." In Weimar, Selbstpreisgabe einer Demokratie, edited by Karl Dietrich Erdmann and Hagen Schulze, 211-49. Droste, 1980.

Bromhead, Alan de, Barry Eichengreen, and Kevin H. O'Rourke. "Political Extremism in the 1920s and 1930s: Do German lessons Generalize?" The Journal of Economic History 73 no. 2 (2013), 372-406.

Büttner, Ursula. "Politische Alternativen zum Brüningschen Deflationskurs. Ein beitrag zur diskussion Uberökonomische Zwangslagen in der Endphase von Weimar." Vierteljahrshefte für Zeitgeschichte 37 no. 2 (1989), 209-51.

Chodorow-Reich, Gabriel, Laura Feiveson, Zachary Liscow, and William Gui Woolston. "Does State Fiscal Relief During Recessions Increase Employment? Evidence from the American Recovery and Reinvestment Act." American Economic Journal: Economic Policy 4 no. 3 (2012), 118-45. 
Correia, Sergio. "A Feasible Estimator for Linear Models with Multi-Way Fixed Effects." Unpublished manuscript, http://scorreia.com/research/hdfe.pdf, 2017.

Dehejia, Rajeev, and Adriana Lleras-Muney. "Booms, Busts, and Babies' Health." The Quarterly Journal of Economics 119 no. 3 (2004), 1091-130.

Dell, Fabien. "Top Incomes in Germany throughout the Twentieth Century: 1891-1998." In Top Incomes over the Twentieth Century: A Contrast between Continental European and EnglishSpeaking Countries, edited by Anthony Barnes Atkinson and Thomas Piketty. Oxford University Press, 2007.

Doerr, Sebastian, Stefan Gissler, José Luis Peydró, and Hans-Joachim Voth. "From Finance to Extremism: The Real Effects of Germany's 1931 Banking Crisis." CEPR Discussion Paper DP12806 (2018).

Dube, Arindrajit, T. William Lester, and Michael Reich. "Minimum Wage effects Across State Borders: Estimates using Contiguous Counties." Review of Economics and Statistics 92 no. 4 (2010), 945-64.

Eichengreen, Barry. Hall of Mirrors: The Great Depression, The Great Recession, and the Uses -and Misuses- of History. Oxford University Press, 2015.

Eichengreen, Barry. The Populist Temptation: Economic Grievance and Political Reaction in the Modern Era. Oxford University Press, 2018.

Eichengreen, Barry, and Tim Hatton. "Interwar Unemployment in International Perspective: An Overview." In Interwar Unemployment in International Perspective, edited by Barry Eichengreen and Tim Hatton, 1-59, Kluwer Academic Publishers, 1988.

Evans, Richard J. The Coming of the Third Reich. Penguin Press, 2003.

Falter, Jürgen, Thomas Lindenberger, Siegfried Schumann. Wahlen und Abstimmungen in der Weimarer Republik. C. H. Beck, 1986.

Feinstein, Charles H., Peter Temin, and Gianni Toniolo. The World Economy between the World Wars. Oxford University Press, 2008.

Feldman, Gerald D. "The Reparations Debate." Diplomacy and Statecraft 16 (2005) 487-98. 
Ferguson, Niall. "Constraints and Room for Manoeuvre in the German Inflation of the Early 1920s." Economic History Review 49 no. 4 (1996), 635-66.

Ferguson, Niall. "The German Inter-War Economy: Political Choice Versus Economic Determinism." In German History since 1800, edited by Mary Fulbrook, 270-71. Arnold, 1997.

Ferguson, Thomas, and Hans-Joachim Voth. "Betting on Hitler - The Value of Political Connections in Nazi Germany," Quarterly Journal of Economics 123 no. 1 (2008), 101-37.

Fetzer, Thiemo. "Did Austerity Cause Brexit?" American Economic Review 109 no. 11 (2019), 3849-86.

Frey, Bruno, and Hannelore Weck. "Hat Arbeitslosigkeit den Aufstieg des Nationalsozialismus Bewirkt?" Jahrbücher für Nationalökonomie und Statistik 196 no. 1 (1981), 1-31.

Fulda, Bernhard. Press and Politics in the Weimar Republic. Oxford University Press, 2009.

Galofré-Vilà, Gregori. "Quantifying the impact of Aid to Dependent Children: An epidemiological framework." Explorations in Economic History, https://doi.org/10.1016/j.eeh.2020. 101332, 2020.

Galofré-Vilà, Gregori, Christopher M. Meissner, Martin McKee and David Stuckler. "The Economic Consequences of the 1953 London Debt Agreement." European Review of Economic History 23 no. 1, 1-29.

Goebbels, Joseph. "Tondokumente und Reden: 1931-02-05, Reichstagsrede," Internet Archive, https://archive.org/details/19310205JosephGoebbelsReichstagsrede3m21s, 1931.

Goldsmith-Pinkham, Paul, Issac Sorkin, and Henry Swift. "Bartik Instruments: What, When, Why, and How." American Economic Review 118 no. 8 (2020), 2586-2624.

Gómez-León, María, and Herman J. de Jong. "Inequality in Turbulent Times: Income Distribution in Germany and Britain, 1900-50." Economic History Review 72 no. 3 (2019), 107398.

Holmes, Thomas J. "The effects of State Policies on the Location of Manufacturing: Evidence from State borders." Journal of Political Economy 106 no. 4 (1998), 667-705.

James, Harold. The German Slump: Politics and Economics 1924-1936. Oxford University Press, 1986. 
Jepsen, Charles Harold. "The Influence of the Multi-Party System on Representative Government in Germany under the Weimar Constitution (1919-1930)." Ph.D. diss., University of Oxford, 1953.

Keynes, John Maynard. The Economic Consequences of the Peace. Macmillan, 1920.

King, Gary, Ori Rosen, Martin Tanner, and Alexander F. Wagner. "Ordinary Economic Voting Behavior in the Extraordinary Election of Adolf Hitler." Journal of Economic History 68 no. 4 (2008), 951-96.

Nakamura, Emi, and Jón Steinsson. "Fiscal Stimulus in a Monetary Union: Evidence from U.S. regions." American Economic Review 104 no. 3 (2014), 753-92.

Newcomer, Mabel. "Fiscal Relations of Central and Local Governments in Germany under the Weimar Constitution." Political Science Quarterly 51 no. 2 (1936), 185-214.

O’Rourke, Kevin H. "Lessons from the Great Depression." EURO Intelligence, 2010.

Ponticelli, Jacopo, and Hans-Joachim Voth. "Austerity and Anarchy: Budget Cuts and Social Unrest in Europe, 1919-2009." Journal of Comparative Economics 48 no. 1 (2020), 1-1

Ritschl, Albrecht. "Reparation Transfers, the Borchardt Hypothesis and the Great Depression in Germany, 1929-32: A Guided Tour for Hard-Headed Keynesians." European Review of Economic History 2 no. 1 (1998), 49-72.

Ritschl, Albrecht. Deutschlands Krise und Konjunktur, 1924-1934. Binnenkonjunktur, Auslandsverschuldung und Reparationsproblem Zwischen Dawes-Plan und Transfersperre. AkademieVerlag. 2002.

Ritschl, Albrecht. "Reparations, Deficits and Debt Default: The Great Depression in Germany." In The Great Depression of the 1930s: Lessons for Today, edited by Nicholas Crafts and Peter Fearon, 110-39. Oxford University Press, 2013a.

Satyanath, Shanker, Nico Voigtländer, and Hans-Joachim Voth. "Bowling for Fascism: Social Capital and the Rise of the Nazi Party." Journal of Political Economy 125 no. 2 (2017), 478-526.

Schuker, Stephen A. American "Reparations" to Germany, 1919-1933: Implications for the Third-World Debt Crisis, Princeton University Press, 1988. 
Shirer, William L. The Rise and Fall of the Third Reich: A History of Nazi Germany. Simon \& Schuster, 1960.

Stögbauer, Christian, and John Komlos. "Averting the Nazi Seizure of Power: A Counterfactual Though Experiment." European Review of Economic History 8 no. 2 (2004), 173-99.

Straumann, Tobias. 1931 Debt, Crisis, and the Rise of Hitler. Oxford University Press, 2019.

Temin, Peter. "The Beginning of the Depression in Germany." Economic History Review 24 no. 2 (1971), 240-4

Temin, Peter. Lessons from the Great Depression. The MIT Press, 1990.

Temin, Peter, and David Vines. Keynes: Useful Economics for the World Economy. The MIT Press, 2014.

Voigtländer, Nico, and Hans-Joachim Voth. "Persecution Perpetuated: The Medieval Origins of Anti-Semitic Violence in Nazi Germany." Quarterly Journal of Economics 127 no. 3 (2012): 1339-92.

Voigtländer, Nico, and Hans-Joachim Voth. "Highway to Hitler." NBER Working Paper No. 20150, Cambridge, MA, 2019.

Voth, Hans-Joachim. "Wages, Investment, and the fate of the Weimar Republic: A Long-Term Perspective." German History 11 no. 3 (1993), 265-292.

Voth, Hans-Joachim. "Roots of war: Hitler's Rise to Power". In The Economics of the Second World War: Seventy-Five Years On, edited by. S. Broadberry and M. Harrison, 9-17, CEPR Press, 2020.

Wueller, Paul Hahan. "The Integration of the German Tax System." Ph.D. diss., University of Columbia, 1933. 
Figure 1. Development of real per capita state spending in Germany, 1926/27-1932/33 (1926/27=100).

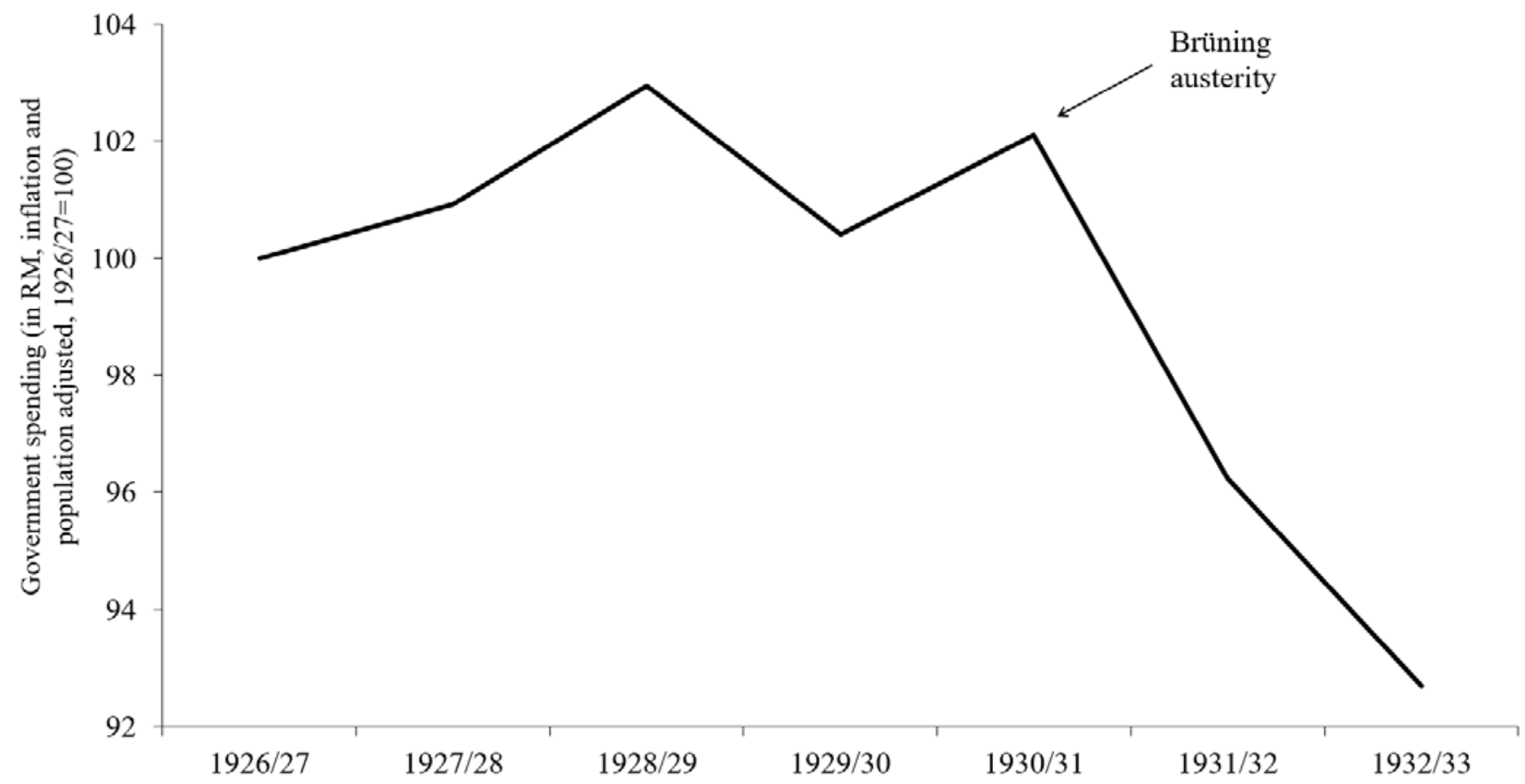

Figure shows the evolution of real per capita government spending between 1926/27 and 1932/33. Nominal state level expenditure as reported in James (1986) following fiscal years and accounting for transfers to other public authorities. Data were originally collected from Official Statistics (Statistiches Jahrbuch für das Deutsche Reich). Nominal expenditure has been adjusted for inflation using the price index (1913/14=100) from Jürgen Sensch in HISTAT-Datenkompilation online (Preisindizes für die Lebenshaltung in Deutschland 1924 bis 2001) and for population using the data from Piketty and Zucman (Data Appendix for Capital is Back, Table DE1). 
Figure 2. City level change in vote for the Nazi party and spending change, 1930-1932.
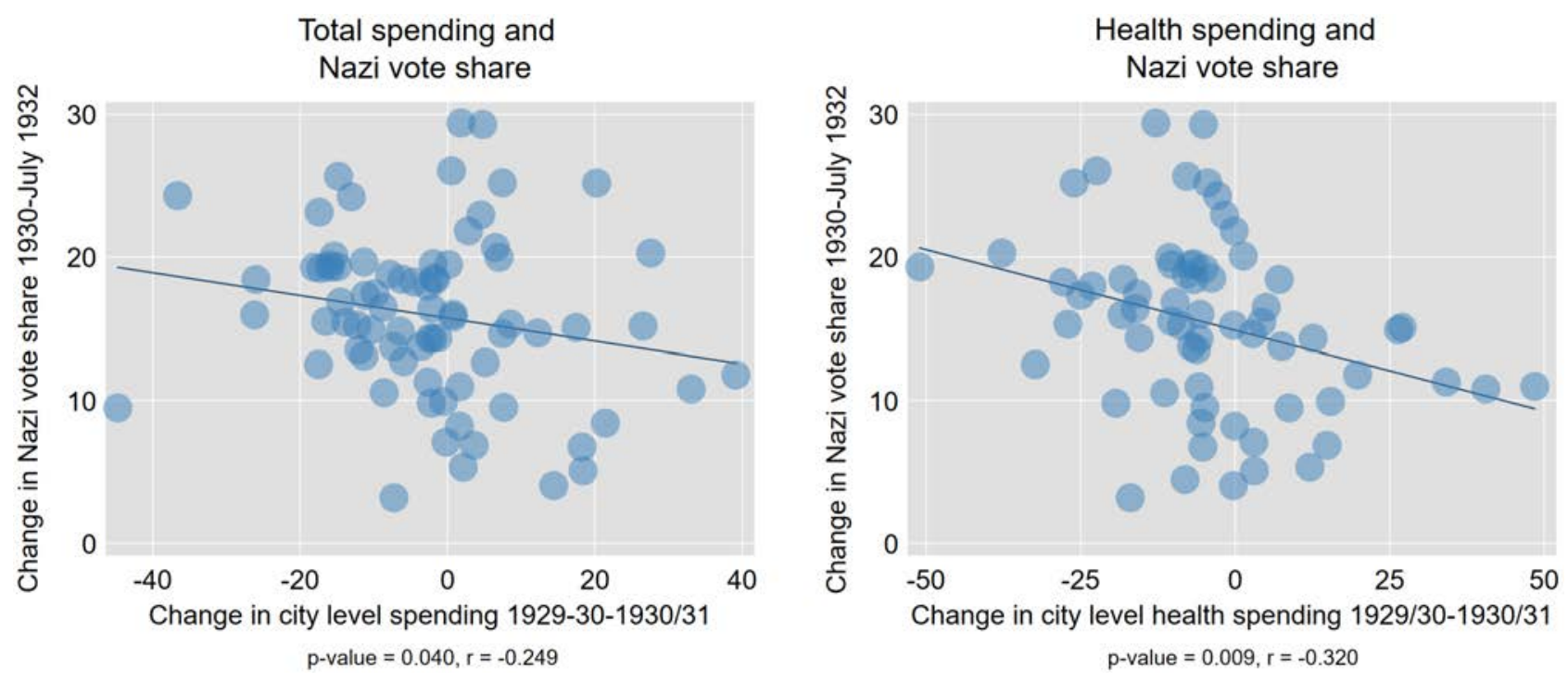

Data on the y-axis is the difference in the vote share going to the Nazi party between the federal elections of September 1930 and July 1932. The x-axis shows change in total city-level government spending in percentage points (left figure) and the change in health and wellbeing city-level government spending (right figure) in percentage points. 
Figure 3. Impact of city expenditures on the Nazi party vote share, elections 1930, 1932 and 1933.
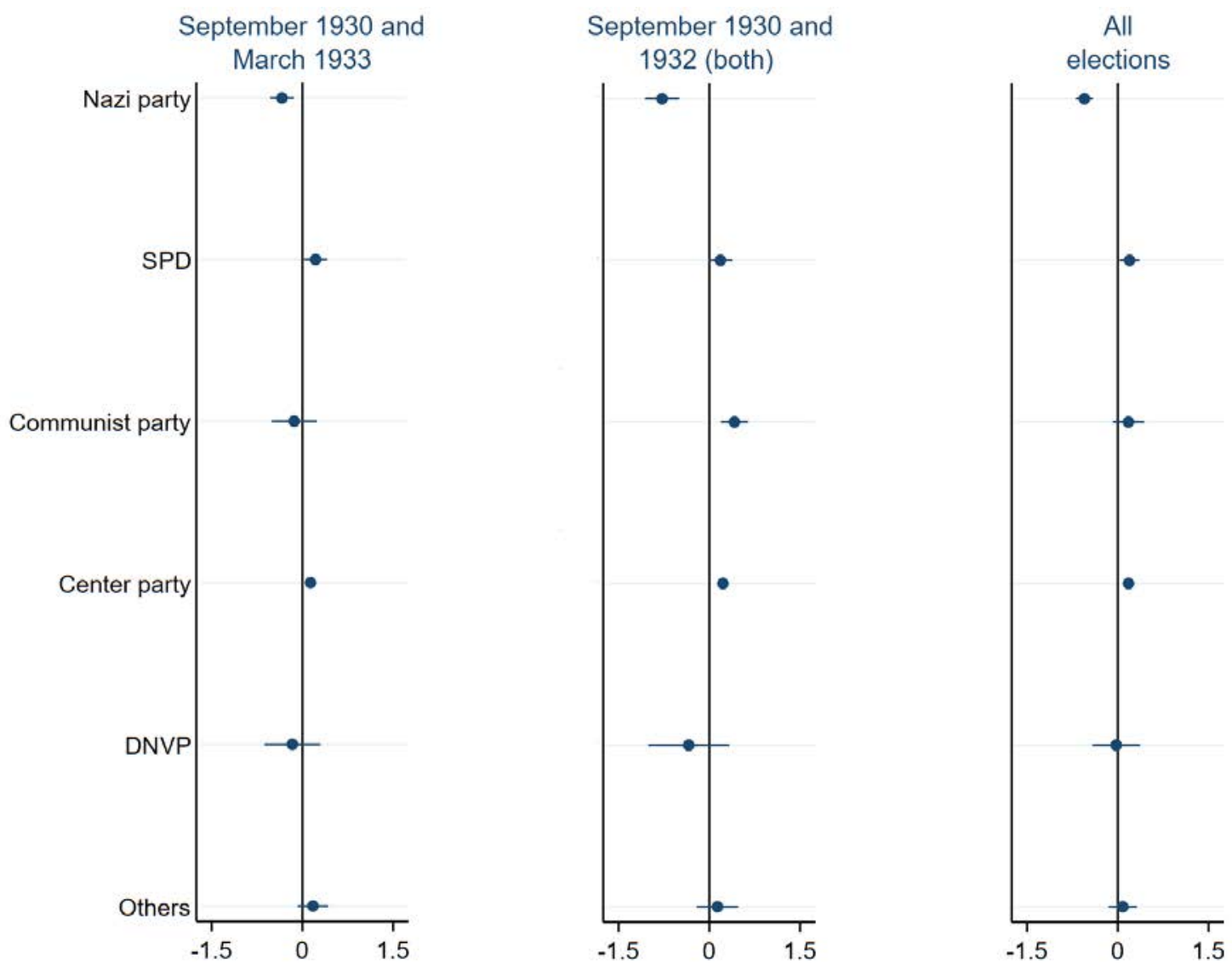

Dependent variable is the percentage share $(\times 100)$ of the valid votes cast going to the main parties in the different elections. Models are estimated independently and adjusted for unemployment and economic output. We use the controls of 1929 for the elections of September 1930, 1931 for the elections of July and November 1932 and 1932 for the elections of March 1933. We use a balanced panel with robust standard errors clustered at the administrative division corresponding to 44 levels. SPD stands for the Social Democratic Party and DNVP for the German National People's Party. In the elections of 1933, the DNVP presented in the elections as part of the Kampffront Schwarz-Weiß-Rot, which was an electoral alliance of three parties: the DNVP, the Stahlhelm and Landbund. All models include city level fixed effects and the forest plot with the elections 1930 and 1932 (both) include a fixed effect for 1931/32 and 'all elections' fixed effects for 1932 and 1933. We standardized all variables with a mean of zero and a standard deviation of one. 
Figure 4. Impact of city expenditures by budget category on the Nazi party vote share, elections 1930, 1932 and 1933.
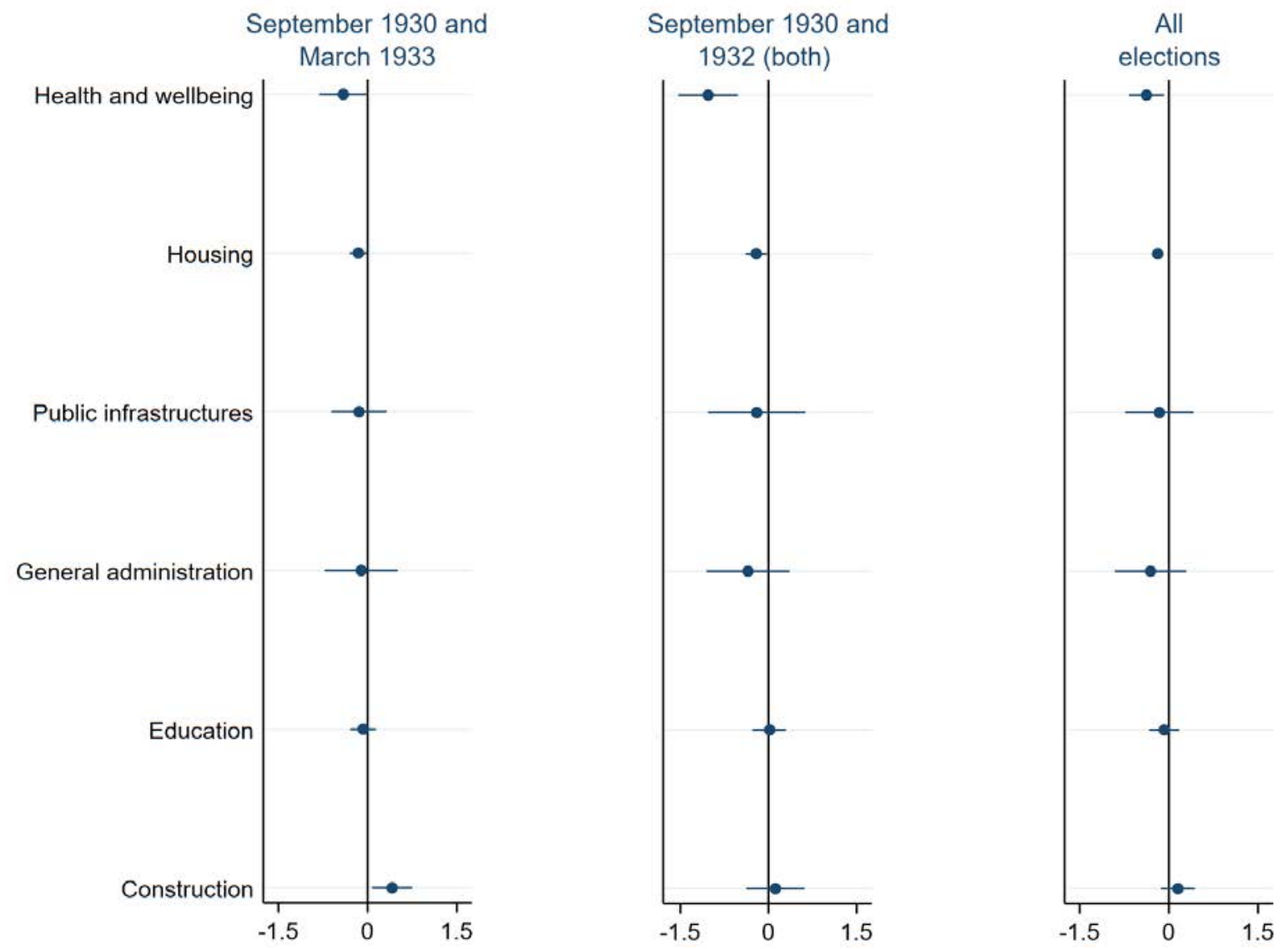

Dependent variable is the percentage share $(\times 100)$ of the valid votes cast going to the Nazi party in the different elections. Models are estimated independently and adjusted for unemployment and economic output. We use the controls of 1929 for the elections of September 1930, 1931 for the elections of July and November 1932 and 1932 for the elections of March 1933. We use a balanced panel with robust standard errors clustered at the administrative division corresponding to 44 levels. All models include city level fixed effects and the forest plot with the elections 1930 and 1932 (both) include a fixed effect for $1931 / 32$ and 'all elections' fixed effects for 1931/32 and 1932/33. We standardized all variables with a mean of zero and a standard deviation of one. 
Table 1: Panel data on the impact of city expenditures on the Nazi party vote share, all national elections 1930-1933.

\begin{tabular}{|c|c|c|c|c|}
\hline & $(1)$ & $(2)$ & $(3)$ & $(4)$ \\
\hline ln Expenditures & $\begin{array}{c}-0.345^{* *} \\
(0.130)\end{array}$ & $\begin{array}{c}-0.415^{* * *} \\
(0.133)\end{array}$ & $\begin{array}{c}-0.351^{* *} \\
(0.169)\end{array}$ & $\begin{array}{c}-0.353^{* *} \\
(0.155)\end{array}$ \\
\hline ln Unemployment & & $\begin{array}{c}0.573 \\
(0.361)\end{array}$ & $\begin{array}{c}0.259 \\
(0.183)\end{array}$ & $\begin{array}{c}0.555^{* * *} \\
(0.139)\end{array}$ \\
\hline ln Economic Output & & $\begin{array}{c}0.033 \\
(0.044)\end{array}$ & $\begin{array}{c}0.033 \\
(0.154)\end{array}$ & $\begin{array}{c}-0.255^{* *} \\
(0.122)\end{array}$ \\
\hline Number of observations & 260 & 260 & 260 & 260 \\
\hline City level fixed effect & $\mathrm{X}$ & $\mathrm{X}$ & $\mathrm{X}$ & $\mathrm{X}$ \\
\hline Fixed effect 1932 & $\mathrm{X}$ & $\mathrm{X}$ & & \\
\hline Fixed effect 1933 & $\mathrm{X}$ & $\mathrm{X}$ & & \\
\hline State $\times$ period fixed effects & & & $\mathrm{X}$ & \\
\hline Admin. division $\times$ period fixed effects & & & & X \\
\hline
\end{tabular}

Dependent variable is the percentage share $(\times 100)$ of the valid votes cast going to the Nazi party in the different elections. Equation 1 is equivalent to the results we show in column 2. We use the controls of 1929 for the elections of September 1930, 1931 for the elections of July and November 1932 and 1932 for the elections of March 1933. We estimated the linear models with many levels of fixed effects as in Correia (2017). We balanced the sample for singleton groups and use a balanced panel with robust standard errors (in parentheses) clustered at the administrative division level corresponding to 44 levels. We standardized all variables with a mean of zero and a standard deviation of one, ${ }^{* * *} \mathrm{p}<0.01,{ }^{* *} \mathrm{p}<0.05,{ }^{*} \mathrm{p}<0.1$. 
Table 2: Impact of city expenditures on the Nazi party vote share using a Bartik instrument, national elections 1930, 1932 and 1933.

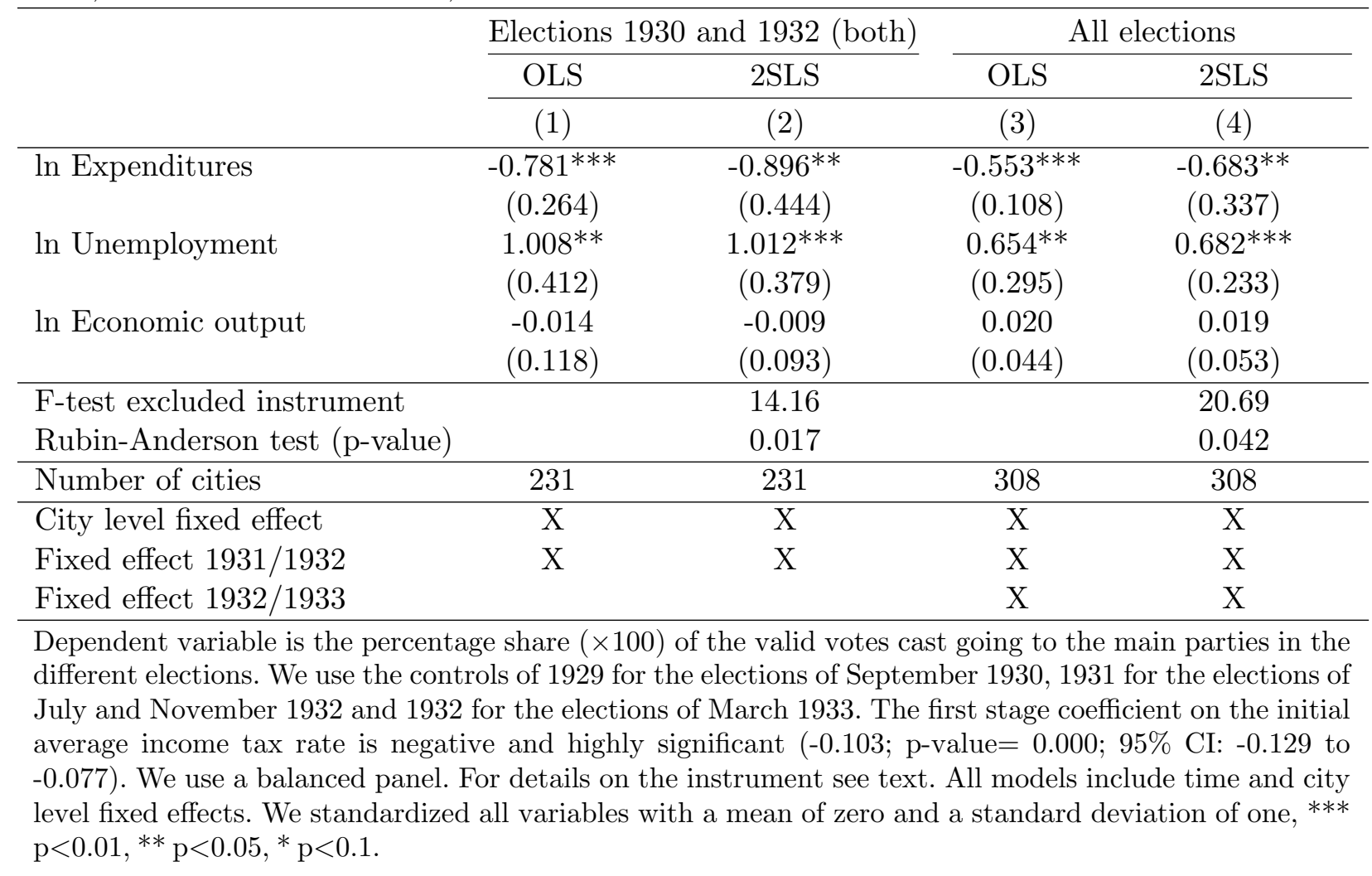


Table 3: Panel data on the impact of city expenditures in health and wellbeing and mortality on the Nazi party vote share, all national elections, 1930-1933.

\begin{tabular}{lccccccc}
\hline & $(1)$ & $(2)$ & $(3)$ & $(4)$ & $(5)$ & $(6)$ & $(7)$ \\
\hline ln Expenditures (health) & $-0.237^{*}$ & & -0.156 & & -0.101 & & -0.197 \\
& $(0.128)$ & & $(0.129)$ & & $(0.110)$ & & $(0.120)$ \\
ln Mortality & & $0.173^{* *}$ & $0.152^{*}$ & $0.232^{* * *}$ & $0.218^{* * *}$ & $0.089^{*}$ & 0.073 \\
& & $(0.071)$ & $(0.085)$ & $(0.062)$ & $(0.071)$ & $(0.052)$ & $(0.053)$ \\
ln Unemployment & $0.785^{* *}$ & $0.690^{* *}$ & $0.726^{* *}$ & $0.663^{* *}$ & $0.688^{* *}$ & $0.739^{* *}$ & $0.777^{* *}$ \\
& $(0.331)$ & $(0.290)$ & $(0.288)$ & $(0.273)$ & $(0.269)$ & $(0.305)$ & $(0.311)$ \\
ln Economic output & -0.029 & -0.074 & -0.069 & -0.073 & -0.071 & -0.028 & -0.030 \\
& $(0.070)$ & $(0.075)$ & $(0.076)$ & $(0.072)$ & $(0.073)$ & $(0.073)$ & $(0.072)$ \\
\hline Number of observations & 150 & 150 & 150 & 150 & 150 & 150 & 150 \\
Number of clusters & 30 & 30 & 30 & 30 & 30 & 30 & 30 \\
\hline $\mathrm{R}^{2}$ & 0.897 & 0.895 & 0.898 & 0.900 & 0.901 & 0.895 & 0.896 \\
\hline City level fixed effect & $\mathrm{X}$ & $\mathrm{X}$ & $\mathrm{X}$ & $\mathrm{X}$ & $\mathrm{X}$ & $\mathrm{X}$ & $\mathrm{X}$ \\
Fixed effect for 1932 & $\mathrm{X}$ & $\mathrm{X}$ & $\mathrm{X}$ & $\mathrm{X}$ & $\mathrm{X}$ & $\mathrm{X}$ & $\mathrm{X}$ \\
Fixed effect for 1933 & $\mathrm{X}$ & $\mathrm{X}$ & $\mathrm{X}$ & $\mathrm{X}$ & $\mathrm{X}$ & $\mathrm{X}$ & $\mathrm{X}$ \\
\hline Baseline & $\mathrm{X}$ & & & & & & \\
All deaths & & $\mathrm{X}$ & $\mathrm{X}$ & & & & $\mathrm{X}$ \\
No deaths from cancer & & & & $\mathrm{X}$ & $\mathrm{X}$ & $\mathrm{X}$ & $\mathrm{X}$ \\
Infant mortality & & & & & & \\
\hline
\end{tabular}

Dependent variable is the percentage share $(\times 100)$ of the valid votes cast going to the Nazi party in the different elections. We use the controls of 1929 for the elections of September 1930, 1931 for the elections of July and November 1932 and 1932 for the elections of March 1933. Column 1 is the baseline specification without controlling for mortality. In columns 2-3 the Crude Death rate is the number of deaths within a city divided by the city level population $(\times 1,000)$, in columns $4-5$ from the Crude Death rate we removed deaths from cancer and unspecified causes of death and in columns 6-7 is the Infant Mortality rate measured as the number of deaths within a city below the age of 1 divided by the number of live births $(\times 1,000)$. We use a balanced panel with robust standard errors (in parentheses) clustered at the district level corresponding to 30 administrative divisions. All models include fixed effects. We also added fixed effects for 1931/32 and $1932 / 33$. We standardized all variables with a mean of zero and a standard deviation of one, ${ }^{* * *} \mathrm{p}<0.01,{ }^{* *}$ $\mathrm{p}<0.05,{ }^{*} \mathrm{p}<0.1$. 
Table 4: Panel data on the impact of district income and wage taxes on the Nazi party vote share using a Bartik instrument, national elections 1930, 1932 and 1933.

\begin{tabular}{|c|c|c|c|c|c|c|c|}
\hline & \multicolumn{2}{|c|}{$\begin{array}{c}\text { Elections } 1930 \\
\text { March } 1933\end{array}$} & \multicolumn{2}{|c|}{$\begin{array}{l}\text { Elections } 1930 \\
\text { and } 1932 \text { (both) }\end{array}$} & \multicolumn{2}{|c|}{$\begin{array}{c}\text { All } \\
\text { elections }\end{array}$} & \multirow{2}{*}{$\begin{array}{c}\begin{array}{c}\text { All } \\
\text { elections }\end{array} \\
2 \text { SLS }\end{array}$} \\
\hline & OLS & OLS & OLS & OLS & OLS & OLS & \\
\hline & (1) & $(2)$ & (3) & (4) & (5) & (6) & $(7)$ \\
\hline \multicolumn{8}{|l|}{ Panel A: Income taxes } \\
\hline ln Income tax rate & $\begin{array}{c}0.164^{* * *} \\
(0.027)\end{array}$ & $\begin{array}{c}0.164^{* * *} \\
(0.042)\end{array}$ & $\begin{array}{c}0.080^{* * *} \\
(0.028)\end{array}$ & $\begin{array}{c}0.080^{* *} \\
(0.029)\end{array}$ & $\begin{array}{c}0.105^{* * *} \\
(0.024)\end{array}$ & $\begin{array}{c}0.105^{* * *} \\
(0.029)\end{array}$ & $\begin{array}{c}0.286^{* * *} \\
(0.035)\end{array}$ \\
\hline ln Wages & $\begin{array}{c}0.021 \\
(0.061)\end{array}$ & $\begin{array}{c}0.021 \\
(0.215)\end{array}$ & $\begin{array}{c}0.088 \\
(0.057)\end{array}$ & $\begin{array}{l}0.088 \\
(0.185)\end{array}$ & $\begin{array}{c}0.059 \\
(0.052)\end{array}$ & $\begin{array}{c}0.059 \\
(0.167)\end{array}$ & $\begin{array}{c}0.062 \\
(0.042)\end{array}$ \\
\hline ln Unemployment & $\begin{array}{c}-0.780^{* * *} \\
(0.206)\end{array}$ & $\begin{array}{l}-0.780 \\
(0.615)\end{array}$ & $\begin{array}{l}-0.452^{*} \\
(0.234)\end{array}$ & $\begin{array}{l}-0.452 \\
(0.814)\end{array}$ & $\begin{array}{c}-0.567^{* * *} \\
(0.214)\end{array}$ & $\begin{array}{l}-0.567 \\
(0.694)\end{array}$ & $\begin{array}{c}-0.399^{* *} \\
(0.166)\end{array}$ \\
\hline ln Economic output & $\begin{array}{l}-0.596 \\
(0.554)\end{array}$ & $\begin{array}{l}-0.596 \\
(0.561)\end{array}$ & $\begin{array}{c}-1.489^{* *} \\
(0.643)\end{array}$ & $\begin{array}{l}-1.489 \\
(0.921)\end{array}$ & $\begin{array}{c}-1.154^{*} \\
(0.599)\end{array}$ & $\begin{array}{l}-1.154 \\
(0.714)\end{array}$ & $\begin{array}{c}-1.207^{* * *} \\
(0.333)\end{array}$ \\
\hline Number of districts & 1,724 & 1,724 & 2,586 & 2,586 & 3,448 & 3,448 & 3,448 \\
\hline District level clustering & $\mathrm{X}$ & & $\mathrm{X}$ & & $\mathrm{X}$ & & \\
\hline State level clustering & & $\mathrm{X}$ & & $\mathrm{X}$ & & $\mathrm{X}$ & \\
\hline District fixed effect & $\mathrm{X}$ & $\mathrm{X}$ & $\mathrm{X}$ & $\mathrm{X}$ & $\mathrm{X}$ & $\mathrm{X}$ & $\mathrm{X}$ \\
\hline Fixed effect for $1932 / 33$ & $\mathrm{X}$ & $\mathrm{X}$ & $\mathrm{X}$ & $\mathrm{X}$ & $\mathrm{X}$ & $\mathrm{X}$ & $\mathrm{X}$ \\
\hline \multicolumn{8}{|l|}{ Panel B: Wage taxes } \\
\hline ln Wage tax rate & $\begin{array}{c}0.191^{* * *} \\
(0.030)\end{array}$ & $\begin{array}{c}0.191^{* * *} \\
(0.051)\end{array}$ & $\begin{array}{c}0.006 \\
(0.035)\end{array}$ & $\begin{array}{c}0.006 \\
(0.007)\end{array}$ & $\begin{array}{c}0.069^{* *} \\
(0.030)\end{array}$ & $\begin{array}{c}0.069 \\
(0.062)\end{array}$ & - \\
\hline ln Wages & $\begin{array}{c}0.065 \\
(0.061)\end{array}$ & $\begin{array}{c}0.065 \\
(0.210)\end{array}$ & $\begin{array}{c}0.088 \\
(0.058)\end{array}$ & $\begin{array}{c}0.088 \\
(0.185)\end{array}$ & $\begin{array}{c}0.064 \\
(0.051)\end{array}$ & $\begin{array}{c}0.064 \\
(0.164)\end{array}$ & - \\
\hline ln Unemployment & $\begin{array}{c}-0.692^{* * *} \\
(0.211)\end{array}$ & $\begin{array}{l}-0.692 \\
(0.603)\end{array}$ & $\begin{array}{c}-0.518^{* *} \\
(0.235)\end{array}$ & $\begin{array}{l}-0.518 \\
(0.752)\end{array}$ & $\begin{array}{c}-0.606^{* * *} \\
(0.219)\end{array}$ & $\begin{array}{l}-0.606 \\
(0.659)\end{array}$ & - \\
\hline ln Economic output & $\begin{array}{l}-0.421 \\
(0.591)\end{array}$ & $\begin{array}{l}-0.421 \\
(0.542)\end{array}$ & $\begin{array}{c}-1.462^{* *} \\
(0.656)\end{array}$ & $\begin{array}{l}-1.462 \\
(0.938)\end{array}$ & $\begin{array}{l}-0.993 \\
(0.627)\end{array}$ & $\begin{array}{l}-0.993 \\
(0.803)\end{array}$ & - \\
\hline Number of districts & 1,724 & 1,724 & 2,586 & 2,586 & 3,448 & 3,448 & - \\
\hline District level clustering & $\mathrm{X}$ & & $\mathrm{X}$ & & $\mathrm{X}$ & & \\
\hline State level clustering & & $\mathrm{X}$ & & $\mathrm{X}$ & & $\mathrm{X}$ & \\
\hline District fixed effect & $\mathrm{X}$ & $\mathrm{X}$ & $\mathrm{X}$ & $\mathrm{X}$ & $\mathrm{X}$ & $\mathrm{X}$ & \\
\hline Fixed effect for $1932 / 33$ & $\mathrm{X}$ & $\mathrm{X}$ & $\mathrm{X}$ & $\mathrm{X}$ & $\mathrm{X}$ & $\mathrm{X}$ & \\
\hline
\end{tabular}

Dependent variable is the percentage share $(\times 100)$ of the valid votes cast going to the Nazi party in the different elections. The average tax rate is calculated as tax revenue divided by total declared taxable income. For wages, unemployment and economic output, we use the controls of 1929 for the elections of September 1930, 1931 for the elections of July and November 1932 and 1932 for the elections of March 1933. For income taxes we use the values for 1928/29, 1929/30 and 1932/33 and for wage taxes 1928/29 and 1932/33. For more details on the tax data see text. We use a balanced panel with standard errors clustered as stated in the table. All models include a district fixed effects and a fixed effect for the fiscal year 1932/33. For the details on column 7 and the instrumental variable used, see text. The F-test of excluded instrument in column 7 is equal to 17.93 and the p-value for the Rubin-Anderson test is 0.001 . The first stage results are statistically significant at 1 percent. We standardized all variables with a mean of zero and a standard deviation of one, $* * * \mathrm{p}<0.01,{ }^{* *} \mathrm{p}<0.05,{ }^{*} \mathrm{p}<0.1$. 
Table 5: The impact of state level austerity on the rise of the Nazi party in the restricted sample of cross district-pairs located on opposite sides of the borders.

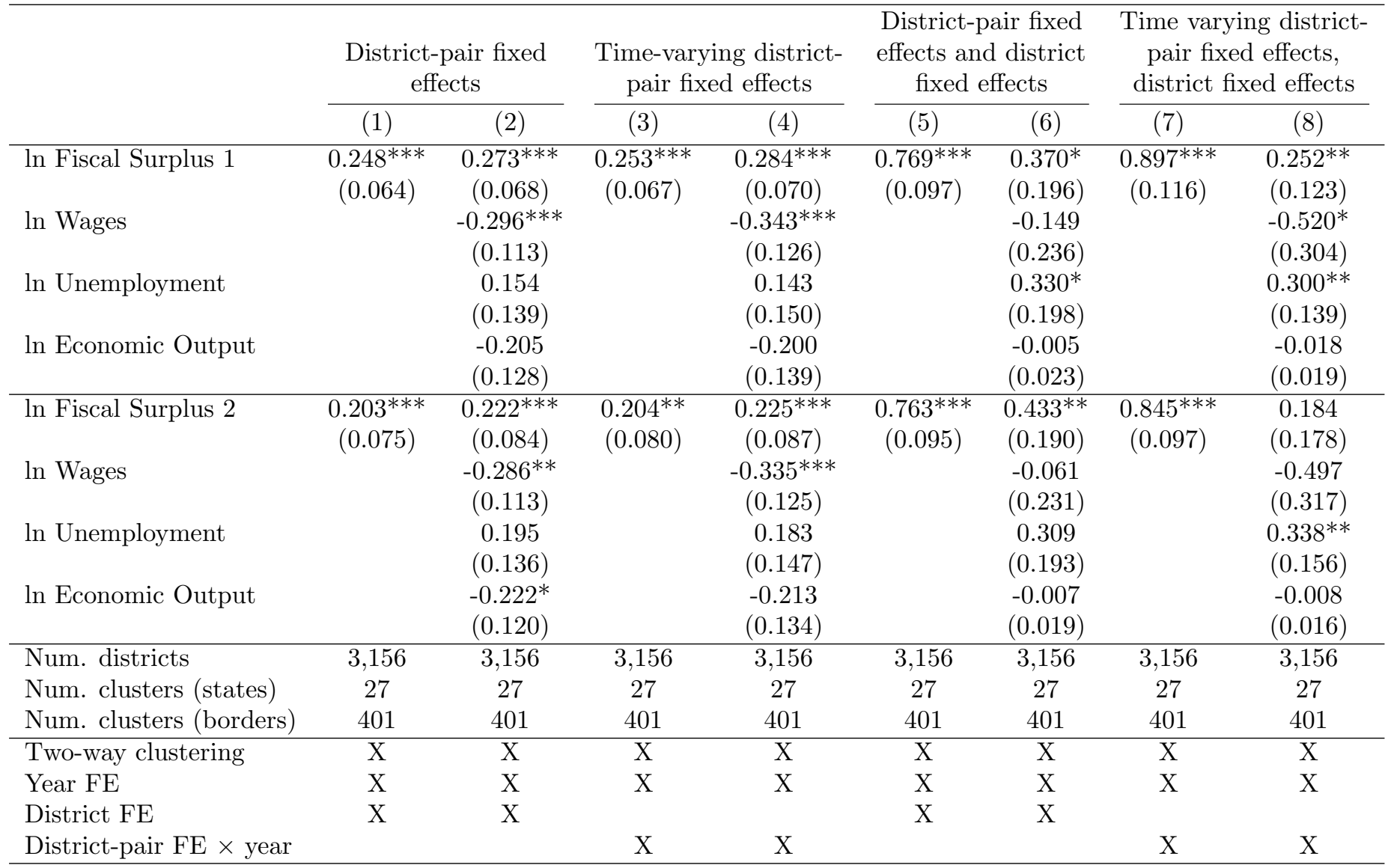

Dependent variable is the percentage share of the valid votes cast going to the Nazi party in the elections of September 1930, July 1932, November 1932 and March 1933. Fiscal surplus is defined as the log of the total state revenue in income or wage taxes minus the log of municipal plus state spending. For the years used in the controls see text. We have 459 districts that lie along a state border (the number of states is equal to 27 and the number of districts is reduced to 401 in the models after accounting for missing data) and for each border-district we match all the neighboring districts that are located on opposite sides of the borders, yielding a total of 1,080 'directed' border-pairs. Each district that lies along a state border, on average has 2.36 pair-districts across the border (with an associated standard deviation of 1.48). The minimum number of pairs for a district is 1 and the maximum is 10. Fiscal surplus 1 combines government spending and wage taxes and Fiscal surplus 2 government spending and income taxes. We use a balanced panel and the methodology from Dube et al. (2010) for two-way clustering with standard errors (in parentheses) clustered at the state and district pair level, ${ }^{* * *} \mathrm{p}<0.01,{ }^{* *} \mathrm{p}<0.05,{ }^{*} \mathrm{p}<0.1$. 
Data Appendix

for online publication 
Figure A1. Cross-district models in differences for the impact of district income taxes on the main political parties vote share. Using differences between (7/1932 and 9/1930),(11/1932 and 9/1930), and (3/1933 and 9/1930) and dropping one state at a time.
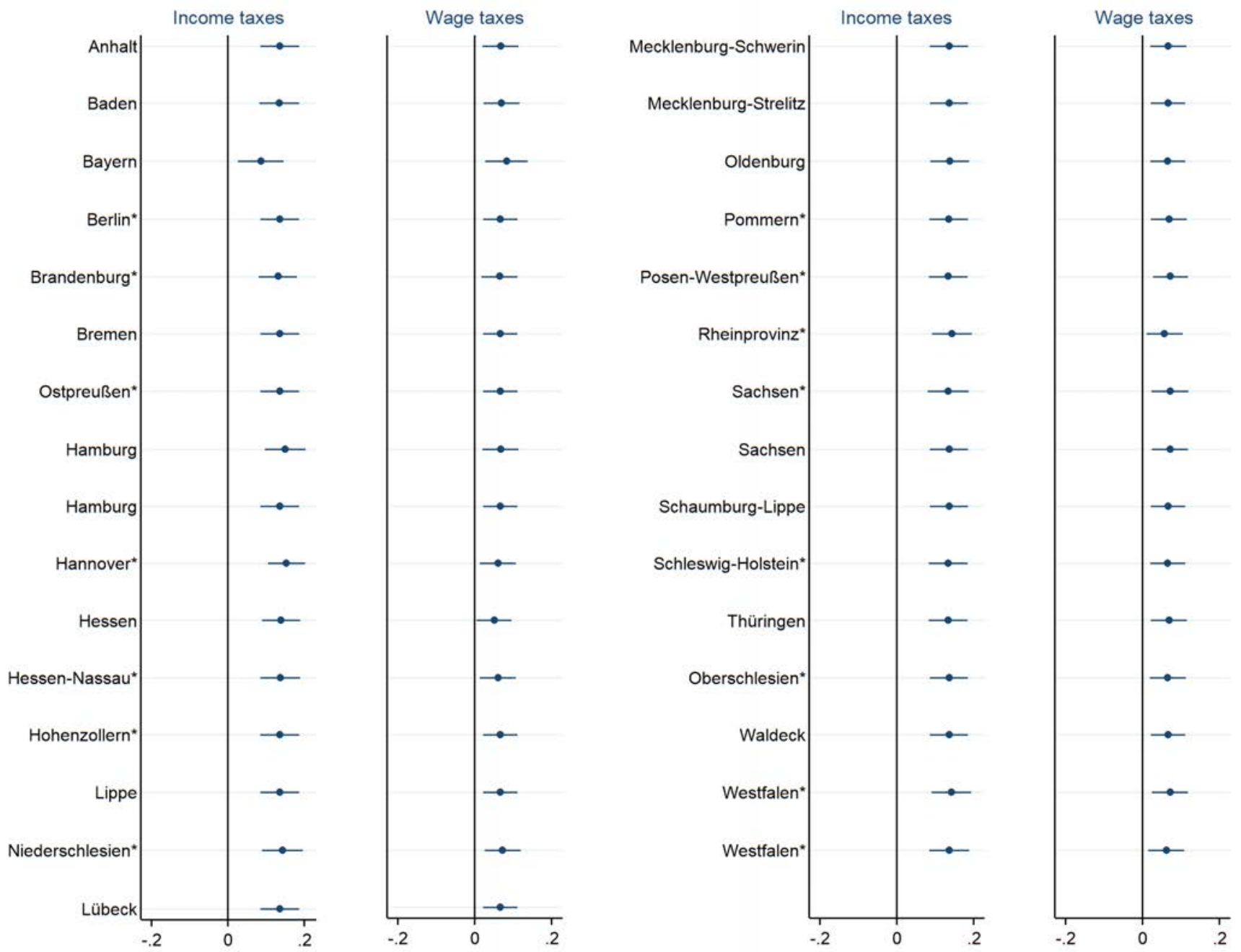

Dependent variable is the percentage share $(\times 100)$ of the valid votes cast going to the different parties in the different elections. The name of the state/province is the one excluded in the regression. The asterisk denotes a Prussian province. We use changes in district level income taxes or wage taxes as a measure of austerity. The income tax rate is calculated as the ratio between total revenue and total taxable income. We include state level fixed effects with standard errors (in parentheses) clustered at the district level. We standardized all variables with a mean of zero and a standard deviation of one. 
Table A1: Main Descriptive Statistics

\begin{tabular}{|c|c|c|c|c|c|}
\hline & Mean & SD & Min & $\operatorname{Max}$ & $\mathrm{N}$ \\
\hline \multicolumn{6}{|l|}{ State and district level data } \\
\hline \multicolumn{6}{|l|}{ Vote cast for the Nazi party ${ }^{1}$} \\
\hline Election September 1930 & 18.84 & 8.96 & 2.20 & 58.80 & 30 \\
\hline Election July 1932 & 39.00 & 14.48 & 7.77 & 83.00 & 30 \\
\hline Election November 1932 & 34.93 & 13.38 & 5.33 & 76.42 & 30 \\
\hline Election March 1933 & 47.14 & 12.11 & 13.29 & 83.01 & 30 \\
\hline \multicolumn{6}{|l|}{ Control variables $^{2}$} \\
\hline$\Delta$ Municipal spending & -11.68 & 4.40 & 2.81 & -24.12 & 30 \\
\hline$\Delta$ State spending & -15.84 & 4.44 & 2.81 & -21.92 & 30 \\
\hline$\Delta$ Municipal plus State spending & -13.21 & 2.05 & -6.57 & -18.46 & 30 \\
\hline$\Delta$ Income tax rate (district level data) & 17.20 & 21.11 & -58.28 & 96.67 & 583 \\
\hline$\Delta$ Wage tax rate (district level data) & -20.70 & 8.27 & -63.33 & 19.83 & 558 \\
\hline$\Delta$ Wages & -20.50 & 3.26 & -16.44 & -30.41 & 30 \\
\hline$\Delta$ Unemployment & 28.17 & 8.41 & 15.67 & 39.70 & 30 \\
\hline$\Delta$ Generation of electricity & -1.37 & 6.30 & -29.85 & 6.93 & 30 \\
\hline \multicolumn{6}{|l|}{ City level data } \\
\hline \multicolumn{6}{|l|}{ Vote cast for the Nazi party ${ }^{1}$} \\
\hline Election September 1930 & 18.04 & 5.86 & 6.75 & 33.39 & 67 \\
\hline Election July 1932 & 33.50 & 8.69 & 16.71 & 50.71 & 67 \\
\hline Election November 1932 & 29.31 & 8.06 & 12.96 & 49.77 & 67 \\
\hline Election March 1933 & 39.61 & 7.29 & 4.40 & 56.31 & 67 \\
\hline \multicolumn{6}{|l|}{ Control variables $^{2}$} \\
\hline$\Delta$ City total spending & -5.55 & 27.53 & 45.00 & -143.57 & 67 \\
\hline$\Delta$ Unemployment & 8.91 & 16.58 & -60.38 & 52.42 & 67 \\
\hline$\Delta$ Construction of new buildings & -64.81 & 22.92 & -98.42 & 20.00 & 67 \\
\hline
\end{tabular}

${ }^{1}$ In percentages, ${ }^{2}$ percentage change and per thousand between 1929/30 and 1932/33). All variables have been adjusted for missing values. Control variables are calculated as percentage changes of nominal values. Tax rates are calculated as tax revenue divided by declared, taxable income. For the income taxes we use the percentage change between 1929 and 1932 and for wage taxes the percentage change between 1928 and 1932. For unemployment we report the change between 1930 and 1932 as city level data begin in 1930. The differences in the change in unemployment are due to how unemployment is being measured. In the state level panel unemployment is defined as a worker who is part of the labor force but not working and in the second panel using city level data it needs to be registered in the local offices. For reference the cumulative decline in the German CPI between 1928 and 1932 was 22.5\% while the aggregate decline in German GDP between 1928 and 1932 was about 30\%. 
Table A2: Panel data on the impact of dynamic effects of city expenditures on the Nazi party vote share, all elections.

\begin{tabular}{lcc}
\hline & $(1)$ & $(2)$ \\
\hline ln Expenditures & $-2.724^{* *}$ & $-1.314^{* *}$ \\
ln Expenditures $\times$ Election July 1932 & $(0.834)$ & $(0.443)$ \\
& -0.106 & -0.047 \\
ln Expenditures $\times$ Election November 1932 & $(0.169)$ & $(0.111)$ \\
& -0.090 & -0.030 \\
$\ln$ Expenditures $\times$ Election March 1933 & $(0.123)$ & $(0.081)$ \\
& -0.227 & -0.120 \\
ln Unemployment & $(0.223)$ & $(0.120)$ \\
& & $-0.589^{*}$ \\
ln Economic Output & & $(0.207)$ \\
& & $-0.987^{* * *}$ \\
\hline Number of observations & & $(0.121)$ \\
\hline City level fixed effect & 308 & 308 \\
Fixed effect 1931/1932 & $\mathrm{X}$ & $\mathrm{X}$ \\
Fixed effect 1932/1933 & $\mathrm{X}$ & $\mathrm{X}$ \\
\hline
\end{tabular}

Dependent variable is the percentage share $(\times 100)$ of the valid votes cast going to the Nazi party in the different elections. We use the controls of 1929 for the elections of September 1930, 1931 for the elections of July and November 1932 and 1932 for the elections of March 1933. Standard errors (in parentheses) are clustered at the administrative division level corresponding to 44 levels and we standardized all variables with a mean of zero and a standard deviation of one, ${ }^{* * *} \mathrm{p}<0.01,{ }^{* *} \mathrm{p}<0.05,{ }^{*} \mathrm{p}<0.1$. 
Table A3: Impact of city expenditures on the Nazi party vote share, elections 1930, 1932 and 1933, with population adjusted controls.

\begin{tabular}{|c|c|c|c|c|c|c|}
\hline & \multicolumn{2}{|c|}{$\begin{array}{c}\text { Elections } 1930 \\
\text { and March } 1933\end{array}$} & \multicolumn{2}{|c|}{$\begin{array}{l}\text { Elections } 1930 \\
\text { and } 1932 \text { (both) }\end{array}$} & \multicolumn{2}{|c|}{$\begin{array}{c}\text { All } \\
\text { elections }\end{array}$} \\
\hline & $(1)$ & $(2)$ & $(3)$ & $(4)$ & $(5)$ & $(6)$ \\
\hline ln Expenditure & $\begin{array}{c}-0.337^{* *} \\
(0.149)\end{array}$ & $\begin{array}{l}-0.080^{*} \\
(0.047)\end{array}$ & $\begin{array}{c}-0.781^{* * *} \\
(0.215)\end{array}$ & $\begin{array}{l}-0.115^{*} \\
(0.065)\end{array}$ & $\begin{array}{c}-0.553^{* * *} \\
(0.108)\end{array}$ & $\begin{array}{c}-0.098^{* * *} \\
(0.029)\end{array}$ \\
\hline ln Unemployment & $\begin{array}{l}1.094 \\
(1.011)\end{array}$ & $\begin{array}{l}0.235^{* *} \\
(0.112)\end{array}$ & $\begin{array}{l}1.008^{* *} \\
(0.412)\end{array}$ & $\begin{array}{c}0.426^{* * *} \\
(0.097)\end{array}$ & $\begin{array}{c}0.654^{* *} \\
(0.295)\end{array}$ & $\begin{array}{c}0.271^{* * *} \\
(0.079)\end{array}$ \\
\hline ln Economic Output & $\begin{array}{c}0.036 \\
(0.072)\end{array}$ & $\begin{array}{c}0.037 \\
(0.053)\end{array}$ & $\begin{array}{l}-0.014 \\
(0.118)\end{array}$ & $\begin{array}{c}0.426^{* * *} \\
(0.097)\end{array}$ & $\begin{array}{c}0.020 \\
(0.044)\end{array}$ & $\begin{array}{c}0.024 \\
(0.029)\end{array}$ \\
\hline Number of observations & 154 & 154 & 231 & 231 & 308 & 308 \\
\hline RHS variables pop. adjusted & & $\mathrm{X}$ & & $\mathrm{X}$ & & $\mathrm{X}$ \\
\hline City level fixed effect & $\mathrm{X}$ & $\mathrm{X}$ & $\mathrm{X}$ & $\mathrm{X}$ & $\mathrm{X}$ & $\mathrm{X}$ \\
\hline Fixed effect 1931/1932 & & & $\mathrm{X}$ & $\mathrm{X}$ & $\mathrm{X}$ & $\mathrm{X}$ \\
\hline Fixed effect $1932 / 1933$ & $\mathrm{X}$ & $\mathrm{X}$ & & & $\mathrm{X}$ & $\mathrm{X}$ \\
\hline
\end{tabular}

Dependent variable is the percentage share $(\times 100)$ of the valid votes cast going to the Nazi party in the different elections. We use the controls of 1929 for the elections of September 1930, 1931 for the elections of July and November 1932 and 1932 for the elections of March 1933. We use a balanced panel with robust standard errors (in parentheses) clustered at the administrative division level corresponding to 44 levels. We standardized all variables with a mean of zero and a standard deviation of one, ${ }^{* * *} \mathrm{p}<0.01,{ }^{* *} \mathrm{p}<0.05,{ }^{*} \mathrm{p}<0.1$. 


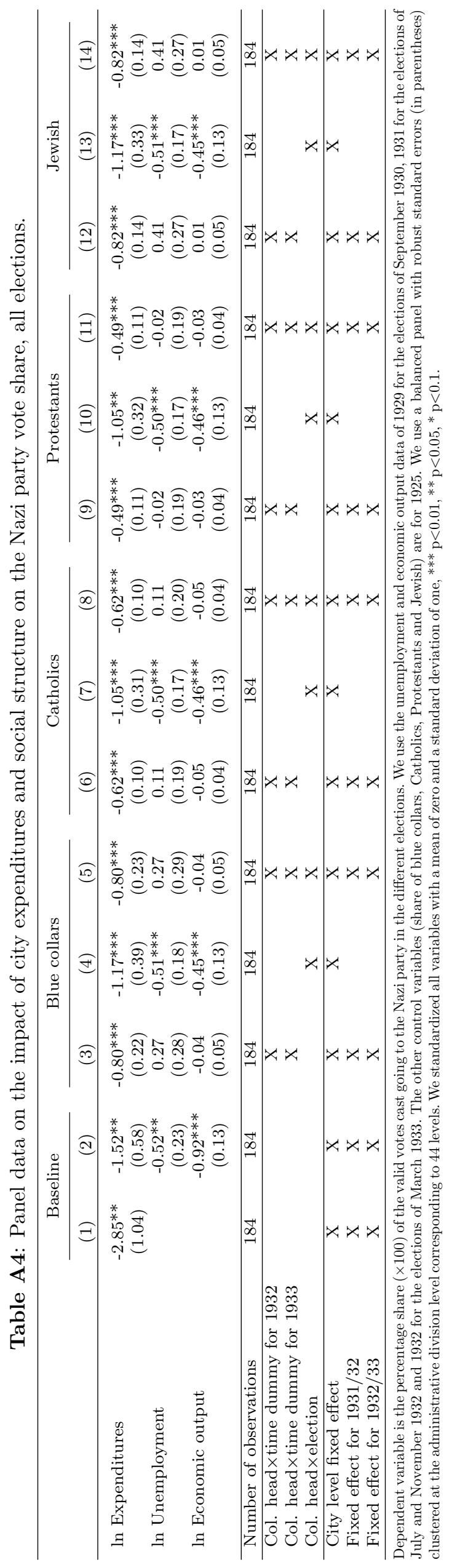


Table A5: Panel data on the impact of city expenditures and welfare recipients on the Nazi party vote share, elections 1930, 1932 and 1933.

\begin{tabular}{|c|c|c|c|c|c|c|c|c|c|}
\hline & \multicolumn{3}{|c|}{ Sept. 1930 and March 1933} & \multicolumn{3}{|c|}{ Sept. 1930 and 1932 (both) } & \multicolumn{3}{|c|}{ All elections } \\
\hline & (1) & $(2)$ & $(3)$ & $(4)$ & (5) & $(6)$ & $(7)$ & (8) & $(9)$ \\
\hline ln Expenditures & $\begin{array}{c}-0.360^{* *} \\
(0.146)\end{array}$ & & $\begin{array}{c}-0.320^{* *} \\
(0.146)\end{array}$ & $\begin{array}{c}-0.778^{* * *} \\
(0.213)\end{array}$ & & $\begin{array}{c}-0.780^{* * *} \\
(0.215)\end{array}$ & $\begin{array}{c}-0.560^{* * *} \\
(0.108)\end{array}$ & & $\begin{array}{c}-0.547^{* * *} \\
(0.113)\end{array}$ \\
\hline ln Welfare recipients & & $\begin{array}{l}-0.205 \\
(0.148)\end{array}$ & $\begin{array}{l}-0.177 \\
(0.134)\end{array}$ & & $\begin{array}{l}-0.025 \\
(0.121)\end{array}$ & $\begin{array}{c}0.013 \\
(0.106)\end{array}$ & & $\begin{array}{l}-0.107 \\
(0.122)\end{array}$ & $\begin{array}{l}-0.066 \\
(0.105)\end{array}$ \\
\hline ln Unemployment & $\begin{array}{c}1.020 \\
(0.996)\end{array}$ & $\begin{array}{c}1.140 \\
(0.984)\end{array}$ & $\begin{array}{l}1.132 \\
(1.008)\end{array}$ & $\begin{array}{l}1.004^{* *} \\
(0.409)\end{array}$ & $\begin{array}{c}0.972^{* *} \\
(0.420)\end{array}$ & $\begin{array}{l}1.012^{* *} \\
(0.421)\end{array}$ & $\begin{array}{c}0.636^{* *} \\
(0.292)\end{array}$ & $\begin{array}{l}0.518^{*} \\
(0.298)\end{array}$ & $\begin{array}{c}0.635^{* *} \\
(0.293)\end{array}$ \\
\hline ln Economic Output & $\begin{array}{c}0.032 \\
(0.071)\end{array}$ & $\begin{array}{c}0.040 \\
(0.066)\end{array}$ & $\begin{array}{c}0.028 \\
(0.071)\end{array}$ & $\begin{array}{l}-0.014 \\
(0.117)\end{array}$ & $\begin{array}{c}-0.046 \\
(0.128)\end{array}$ & $\begin{array}{l}-0.013 \\
(0.116)\end{array}$ & $\begin{array}{c}0.019 \\
(0.044)\end{array}$ & $\begin{array}{c}0.019 \\
(0.043)\end{array}$ & $\begin{array}{c}0.017 \\
(0.043)\end{array}$ \\
\hline Number observations & 156 & 156 & 156 & 234 & 234 & 234 & 312 & 312 & 312 \\
\hline City level fixed effect & $\mathrm{X}$ & $\mathrm{X}$ & $\mathrm{X}$ & $\mathrm{X}$ & $\mathrm{X}$ & $\mathrm{X}$ & $\mathrm{X}$ & $\mathrm{X}$ & $\mathrm{X}$ \\
\hline Fixed effect 1931 & & & & $\mathrm{X}$ & $\mathrm{X}$ & $\mathrm{X}$ & $\mathrm{X}$ & $\mathrm{X}$ & $\mathrm{X}$ \\
\hline Fixed effect 1932 & $\mathrm{X}$ & $\mathrm{X}$ & $\mathrm{X}$ & & & & $\mathrm{X}$ & $\mathrm{X}$ & $\mathrm{X}$ \\
\hline
\end{tabular}

Dependent variable is the percentage share $(\times 100)$ of the valid votes cast going to the Nazi party in the different elections. We use the controls of 1929 for the elections of September 1930, 1931 for the elections of July and November 1932 and 1932 for the elections of March 1933. Data from the number of Welfare recipients are from the Statistik des deutschen Reichs, Band 421 (Die öffentliche Fürsorge im Deutschen Reich) and refers to the number of public welfare recipients in open care (Die öffentliche Fúrsorge). We use a balanced panel with robust standard errors (in parentheses) clustered at the administrative division level corresponding to 44 levels. We standardized all variables with a mean of zero and a standard deviation of one, ${ }^{* * *} \mathrm{p}<0.01,{ }^{* *} \mathrm{p}<0.05,{ }^{*} \mathrm{p}<0.1$. 
Table A6: Cross-city models in differences for the impact of city spending on the Nazi party vote share. Using differences between (9/1930 and 7/1932), (9/1930 and 11/1932) and $(11 / 1932$ and $3 / 1933)$.

\begin{tabular}{|c|c|c|c|c|c|c|}
\hline & $\frac{\text { OLS }}{(1)}$ & $\frac{\text { 1st stage }}{(2)}$ & $\frac{2 \mathrm{SLS}}{(3)}$ & $\frac{\text { OLS }}{(4)}$ & $\frac{\text { 1st stage }}{(5)}$ & $\frac{2 \mathrm{SLS}}{(6)}$ \\
\hline$\% \Delta$ Expenditures & $\begin{array}{c}-0.235^{* * *} \\
(0.047)\end{array}$ & $\begin{array}{c}0.456^{* * *} \\
(0.057)\end{array}$ & $\begin{array}{c}-0.276^{* *} \\
(0.130)\end{array}$ & $\begin{array}{c}-0.255^{* * *} \\
(0.046)\end{array}$ & $\begin{array}{c}0.454^{* * *} \\
(0.056)\end{array}$ & $\begin{array}{c}-0.290^{* *} \\
(0.132)\end{array}$ \\
\hline$\% \Delta$ Unemployment & & & & $\begin{array}{c}0.347^{* *} \\
(0.145)\end{array}$ & $\begin{array}{c}0.334^{* *} \\
(0.019)\end{array}$ & $\begin{array}{c}0.360^{* *} \\
(0.156)\end{array}$ \\
\hline$\% \Delta$ Economic Output & & & & $\begin{array}{l}-0.014 \\
(0.062)\end{array}$ & $\begin{array}{l}0.102^{*} \\
(0.056)\end{array}$ & $\begin{array}{c}-0.011 \\
(0.063)\end{array}$ \\
\hline Number of observations & 234 & 234 & 234 & 234 & 234 & 234 \\
\hline Kleibergen-Paap & & & 0.024 & & & 0.023 \\
\hline Anderson-Rubin & & & 0.017 & & & 0.013 \\
\hline Hansen & & & 0.000 & & & 0.000 \\
\hline
\end{tabular}

Dependent variable is the change in the percentage share $(\times 100)$ of valid votes received by the Nazi party at the city level. We use the controls of 1929 for the elections of September 1930, 1931 for the elections of July and November 1932 and 1932 for the elections of March 1933. We estimated the following model: $\Delta$ Nazi $d t=\alpha+\beta_{1}\left(\% \Delta\right.$ Average tax rate $\left.(a)_{s} / d t\right)+\beta_{2}(\% \Delta$ Wages $s t)+\beta_{3}(\% \Delta$ Unemployment st $)+\beta 4(\% \Delta$ Economic Output st $)+e d t$. The average rate of income or wage taxes (denoted by $a)$ is calculated as the ratio of tax revenue divided by total declared taxable income. Tax rates are indexed by districts $d$, or states, $s, t$ is an election period (September 1930, July 1932, November 1932 or March 1933). Since we do not have annual data on taxes, we linked the income taxes for the fiscal year 1929/30 to the elections of September 1930 and the taxes for the fiscal year 1932/33 to the elections of 1932 and 1933 . Since wage taxes are unavailable for the fiscal year 1929/30, we had to link the wage taxes for 1928/29 to the elections of 1930 and the taxes for 1932/33 to the elections of 1932 and 1933. Nazi denotes the percentage point vote share of the Nazi party in the four different federal elections, the difference $\Delta$ is taken between the three later elections and the initial election of September 1930. We use a balanced panel with robust standard errors (in parentheses) clustered at the administrative division level corresponding to 44 levels. For the description of the instrument see text. We standardized all variables with a mean of zero and a standard deviation of one, ${ }^{* * *} \mathrm{p}<0.01, * * \mathrm{p}<0.05, *$ $\mathrm{p}<0.1$. 
Table A7: Cross-district models in differences for the impact of district income and wage taxes on the Nazi party vote share. Using differences between (7/1932 and 9/1930), (11/1932 and 9/1930), and $(3 / 1933$ and $9 / 1930)$.

\begin{tabular}{|c|c|c|c|c|c|c|c|c|}
\hline & $\begin{array}{c}\text { OLS } \\
(1)\end{array}$ & $\frac{\text { OLS }}{(2)}$ & $\begin{array}{c}\text { OLS } \\
(3)\end{array}$ & $\begin{array}{c}\text { OLS } \\
(4)\end{array}$ & $\begin{array}{c}\text { OLS } \\
(5)\end{array}$ & $\begin{array}{c}\text { OLS } \\
(6)\end{array}$ & $\begin{array}{c}\text { 2SLS } \\
(7)\end{array}$ & $\begin{array}{c}\text { 2SLS } \\
(8)\end{array}$ \\
\hline \multicolumn{9}{|l|}{ Panel A: Income taxes } \\
\hline$\% \Delta$ Avg. Income tax rate & $\begin{array}{c}0.116^{* * *} \\
(0.029)\end{array}$ & $\begin{array}{c}0.116^{* * *} \\
(0.031)\end{array}$ & $\begin{array}{c}0.135^{* * *} \\
(0.030)\end{array}$ & $\begin{array}{c}0.114^{* * *} \\
(0.030)\end{array}$ & $\begin{array}{c}0.108^{* * *} \\
(0.027)\end{array}$ & $\begin{array}{c}0.108^{* * *} \\
(0.032)\end{array}$ & $\begin{array}{c}0.454^{* * *} \\
(0.073)\end{array}$ & $\begin{array}{c}0.454^{* * *} \\
(0.092)\end{array}$ \\
\hline$\% \Delta$ Wages & $\begin{array}{c}0.039 \\
(0.029)\end{array}$ & $\begin{array}{c}0.039 \\
(0.094)\end{array}$ & $\begin{array}{c}0.060 \\
(0.056)\end{array}$ & $\begin{array}{c}0.032 \\
(0.028)\end{array}$ & $\begin{array}{c}0.062^{* *} \\
(0.027)\end{array}$ & $\begin{array}{c}0.062 \\
(0.096)\end{array}$ & $\begin{array}{c}0.043 \\
(0.032)\end{array}$ & $\begin{array}{c}0.043 \\
(0.093)\end{array}$ \\
\hline$\% \Delta$ Unemployment & $\begin{array}{c}-0.086^{* * *} \\
(0.030)\end{array}$ & $\begin{array}{l}-0.086 \\
(0.095)\end{array}$ & $\begin{array}{c}-0.282^{* * *} \\
(0.056)\end{array}$ & $\begin{array}{c}-0.095^{* * *} \\
(0.030)\end{array}$ & $\begin{array}{l}-0.033 \\
(0.024)\end{array}$ & $\begin{array}{l}-0.033 \\
(0.081)\end{array}$ & $\begin{array}{l}-0.048 \\
(0.034)\end{array}$ & $\begin{array}{l}-0.048 \\
(0.101)\end{array}$ \\
\hline$\% \Delta$ Economic output & $\begin{array}{c}-0.067^{*} \\
(0.036)\end{array}$ & $\begin{array}{l}-0.067 \\
(0.049)\end{array}$ & $\begin{array}{l}-0.225 \\
(0.466)\end{array}$ & $\begin{array}{c}-0.067^{*} \\
(0.036)\end{array}$ & $\begin{array}{l}-0.044 \\
(0.034)\end{array}$ & $\begin{array}{l}-0.044 \\
(0.033)\end{array}$ & $\begin{array}{c}-0.072^{* *} \\
(0.036)\end{array}$ & $\begin{array}{l}-0.072 \\
(0.050)\end{array}$ \\
\hline Lagged Nazi vote share & & & & & $\begin{array}{c}0.368^{* * *} \\
(0.019)\end{array}$ & $\begin{array}{c}0.368^{* * *} \\
(0.067)\end{array}$ & & \\
\hline Number of districts & 2,586 & 2,586 & 2,586 & 2,586 & 2,586 & 2,586 & 2,586 & 2,586 \\
\hline Anderson-Rubin & & & & & & & 0.000 & 0.000 \\
\hline Stock-Wright & & & & & & & 0.000 & 0.000 \\
\hline Kleibergen-Paap & & & & & & & 0.000 & 0.014 \\
\hline Admin. div. level clust. & $\mathrm{X}$ & & $\mathrm{X}$ & $\mathrm{X}$ & $\mathrm{X}$ & & $\mathrm{X}$ & \\
\hline State level clustering & & $\mathrm{X}$ & & & & $\mathrm{X}$ & & $\mathrm{X}$ \\
\hline State fixed effects & & & $\mathrm{X}$ & & & & & \\
\hline Population weighted & & & & $\mathrm{X}$ & & & & \\
\hline \multicolumn{9}{|l|}{ Panel B: Wage taxes } \\
\hline$\% \Delta$ Avg. Wage tax rate & $\begin{array}{c}0.065^{* *} \\
(0.028)\end{array}$ & $\begin{array}{c}0.065 \\
(0.058)\end{array}$ & $\begin{array}{c}0.066^{* *} \\
(0.027)\end{array}$ & $\begin{array}{c}0.071^{* * *} \\
(0.028)\end{array}$ & $\begin{array}{c}0.072^{* * *} \\
(0.022)\end{array}$ & $\begin{array}{l}0.072^{*} \\
(0.040)\end{array}$ & & \\
\hline$\% \Delta$ Wages & $\begin{array}{l}0.048^{*} \\
(0.029)\end{array}$ & $\begin{array}{c}0.048 \\
(0.092)\end{array}$ & $\begin{array}{c}0.085 \\
(0.072)\end{array}$ & $\begin{array}{c}0.042 \\
(0.029)\end{array}$ & $\begin{array}{c}0.073^{* * *} \\
(0.027)\end{array}$ & $\begin{array}{c}0.073 \\
(0.095)\end{array}$ & & \\
\hline$\% \Delta$ Unemployment & $\begin{array}{c}-0.086^{* * *} \\
(0.031)\end{array}$ & $\begin{array}{l}-0.086 \\
(0.090)\end{array}$ & $\begin{array}{c}-0.288^{* * *} \\
(0.066)\end{array}$ & $\begin{array}{c}-0.093^{* * *} \\
(0.030)\end{array}$ & $\begin{array}{c}-0.030 \\
(0.024)\end{array}$ & $\begin{array}{l}-0.030 \\
(0.080)\end{array}$ & & \\
\hline$\% \Delta$ Economic output & $\begin{array}{c}-0.063^{*} \\
(0.037)\end{array}$ & $\begin{array}{l}-0.063 \\
(0.050)\end{array}$ & $\begin{array}{c}-0.366 \\
(0.729)\end{array}$ & $\begin{array}{r}-0.062^{*} \\
(0.037)\end{array}$ & $\begin{array}{l}-0.039 \\
(0.035)\end{array}$ & $\begin{array}{l}-0.039 \\
(0.032)\end{array}$ & & \\
\hline Lagged Nazi vote share & & & & & $\begin{array}{c}0.372^{* * *} \\
(0.019)\end{array}$ & $\begin{array}{c}0.372^{* * *} \\
(0.069)\end{array}$ & & \\
\hline Number of districts & 2,586 & 2,586 & 2,586 & 2,586 & 2,586 & 2,586 & & \\
\hline $\begin{array}{l}\text { Admin. div. level clust. } \\
\text { State level clustering }\end{array}$ & $\mathrm{X}$ & $\mathrm{X}$ & $\mathrm{X}$ & $\mathrm{X}$ & $\mathrm{X}$ & $\mathrm{X}$ & & \\
\hline State fixed effects & & & $\mathrm{X}$ & & & & & \\
\hline Population weighted & & & & $\mathrm{X}$ & & & & \\
\hline
\end{tabular}




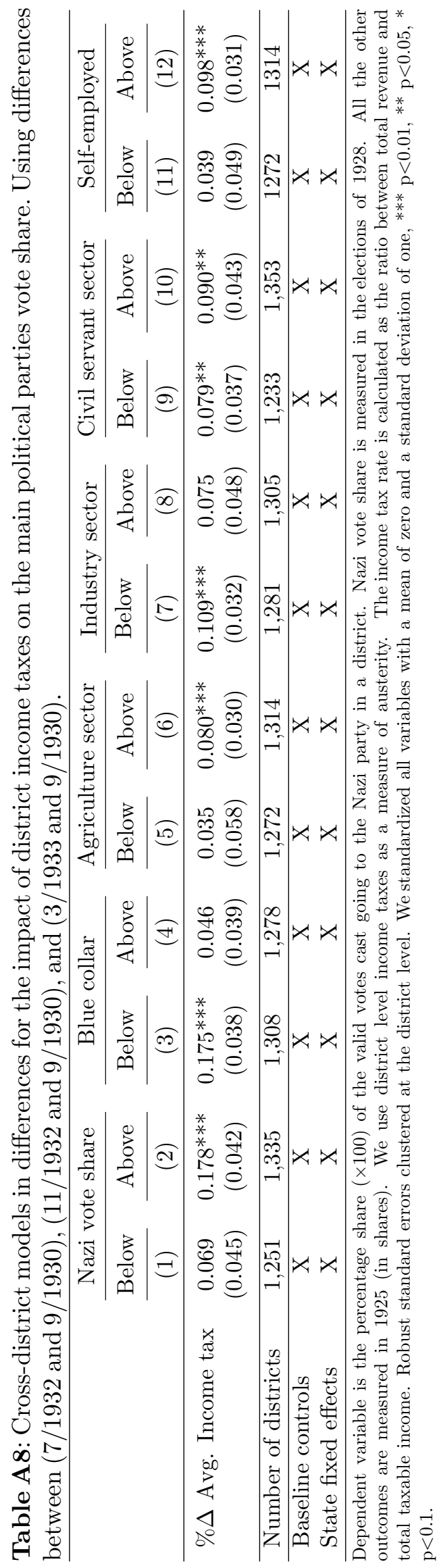


Table A9: Cross-district models in differences for the impact of district income and wage taxes on the main political parties vote share. Using differences between (7/1932 and 9/1930), (11/1932 and 9/1930), and (3/1933 and 9/1930). Non-standardized coefficients.

\begin{tabular}{|c|c|c|c|c|c|c|}
\hline & Nazi & $\mathrm{SPD}$ & $\mathrm{KPD}$ & Zentrum & DNVP & Other \\
\hline & $(1)$ & $(2)$ & $(3)$ & $(4)$ & $(5)$ & $(6)$ \\
\hline \multirow[b]{2}{*}{$\% \Delta$ Avg. Income tax rate } & \multicolumn{6}{|c|}{ Panel A: Income taxes } \\
\hline & $\begin{array}{c}0.050^{* * *} \\
(0.017)\end{array}$ & $\begin{array}{c}0.006 \\
(0.004)\end{array}$ & $\begin{array}{l}-0.003 \\
(0.002)\end{array}$ & $\begin{array}{l}-0.009^{*} \\
(0.005)\end{array}$ & $\begin{array}{c}0.004 \\
(0.005)\end{array}$ & $\begin{array}{c}-0.048^{* *} \\
(0.018)\end{array}$ \\
\hline Number of districts & 2,586 & 2,586 & 2,586 & 2,586 & 2,586 & 2,586 \\
\hline Standard controls & $\mathrm{X}$ & $\mathrm{X}$ & $\mathrm{X}$ & $\mathrm{X}$ & $\mathrm{X}$ & $\mathrm{X}$ \\
\hline State level fixed effects & $\mathrm{X}$ & $\mathrm{X}$ & $\mathrm{X}$ & $\mathrm{X}$ & $\mathrm{X}$ & $\mathrm{X}$ \\
\hline District level clustering & $\mathrm{X}$ & $\mathrm{X}$ & $\mathrm{X}$ & $\mathrm{X}$ & $\mathrm{X}$ & $\mathrm{X}$ \\
\hline \multicolumn{7}{|c|}{ Panel B: Wage taxes } \\
\hline$\% \Delta$ Avg. Wage tax rate & $\begin{array}{c}0.097^{* *} \\
(0.039)\end{array}$ & $\begin{array}{c}0.062 \\
(0.039)\end{array}$ & $\begin{array}{c}0.010 \\
0.016)\end{array}$ & $\begin{array}{c}-0.074^{* * *} \\
(0.024)\end{array}$ & $\begin{array}{l}-0.025 \\
(0.015)\end{array}$ & $\begin{array}{l}-0.069 \\
(0.042)\end{array}$ \\
\hline Number of districts & 2,586 & 2,586 & 2,586 & 2,586 & 2,586 & 2,586 \\
\hline Standard controls & $\mathrm{X}$ & $\mathrm{X}$ & $\mathrm{X}$ & $\mathrm{X}$ & $\mathrm{X}$ & $\mathrm{X}$ \\
\hline State level fixed effects & $\mathrm{X}$ & $\mathrm{X}$ & $\mathrm{X}$ & $\mathrm{X}$ & $\mathrm{X}$ & $\mathrm{X}$ \\
\hline District level clustering & $\mathrm{X}$ & $\mathrm{X}$ & $\mathrm{X}$ & $\mathrm{X}$ & $\mathrm{X}$ & $\mathrm{X}$ \\
\hline \multicolumn{7}{|c|}{$\begin{array}{l}\text { Dependent variable is the percentage share }(\times 100) \text { of the valid votes cast going to the different parties in the different elections. We us } \\
\text { district level income or wage taxes as a measure of austerity. The tax rate is calculated as the ratio between total revenue and total taxabl } \\
\text { income. We cluster standard errors (in parentheses) as stated in the table. All models include state level fixed effects with standard error } \\
\text { clustered at the state level. Clustering at the district level report very similar results. SPD (Sozialdemokratische Partei) is the Socia } \\
\text { Democratic party; KPD }(\text { Kommunistische Partei Deutschlands) the Communist party; and Zentrum (Deutsche Zentrumspartei) th } \\
\text { Center party, }{ }^{* * *} \mathrm{p}<0.01,{ }^{* *} \mathrm{p}<0.05,{ }^{*} \mathrm{p}<0.1 \text {. }\end{array}$} \\
\hline
\end{tabular}


Table A10: Cross-district models in differences for the impact of district income and wage taxes on the Nazi party vote share using percentage point change instead of percentage change in income and wage taxes. Using differences between (7/1932 and 9/1930), (11/1932 and 9/1930), and $(3 / 1933$ and $9 / 1930))$.

\begin{tabular}{|c|c|c|c|c|c|c|c|c|}
\hline & \multicolumn{4}{|c|}{ Average Income taxes } & \multicolumn{4}{|c|}{ Average Wage taxes } \\
\hline & (1) & $(2)$ & $(3)$ & (4) & (5) & $(6)$ & $(7)$ & (8) \\
\hline Avg. taxes & $\begin{array}{c}0.093^{* * *} \\
(0.033)\end{array}$ & $\begin{array}{c}0.087^{* * *} \\
(0.033)\end{array}$ & $\begin{array}{c}0.093^{* * *} \\
(0.025)\end{array}$ & $\begin{array}{c}0.087^{* * *} \\
(0.028)\end{array}$ & $\begin{array}{c}0.118^{* * *} \\
(0.026)\end{array}$ & $\begin{array}{c}0.115^{* * *} \\
(0.027)\end{array}$ & $\begin{array}{l}0.018^{* *} \\
(0.057)\end{array}$ & $\begin{array}{l}0.115^{*} \\
(0.057)\end{array}$ \\
\hline$\% \Delta$ Wages & & $\begin{array}{c}0.039 \\
(0.029)\end{array}$ & & $\begin{array}{c}0.039 \\
(0.093)\end{array}$ & & $\begin{array}{l}0.055^{*} \\
(0.029)\end{array}$ & & $\begin{array}{c}0.055 \\
(0.088)\end{array}$ \\
\hline$\% \Delta$ Unemployment & & $\begin{array}{c}-0.092^{* * *} \\
(0.030)\end{array}$ & & $\begin{array}{l}-0.092 \\
(0.093)\end{array}$ & & $\begin{array}{c}-0.079 * * * \\
(0.031)\end{array}$ & & $\begin{array}{l}-0.079 \\
(0.092)\end{array}$ \\
\hline$\% \Delta$ Econ. output & & $\begin{array}{r}-0.067^{*} \\
(0.036)\end{array}$ & & $\begin{array}{l}-0.067 \\
(0.048)\end{array}$ & & $\begin{array}{l}-0.063^{*} \\
(0.038)\end{array}$ & & $\begin{array}{l}-0.06 \\
(0.050)\end{array}$ \\
\hline Number of districts & 2,586 & 2,586 & 2,586 & 2,586 & 2,586 & 2,586 & 2,586 & 2,586 \\
\hline $\begin{array}{l}\text { District level clust. } \\
\text { State level clustering }\end{array}$ & $\mathrm{X}$ & $\mathrm{X}$ & $\mathrm{X}$ & $\mathrm{X}$ & $\mathrm{X}$ & $\mathrm{X}$ & $\mathrm{X}$ & $\mathrm{X}$ \\
\hline
\end{tabular}

Dependent variable is the percentage share $(\times 100)$ of the valid votes cast going to the Nazi party in the different elections. We use income level wage taxes as a measure of austerity. Taxes are calculated as the percentage point change instead as percentage change. We cluster standard errors (in parentheses) at the district level in columns 1,2,5 and 6 and at the state level in columns $3,4,7$ and 8 . The method of estimation is least squares and we standardized all variables with a mean of zero and a standard deviation of one, ${ }^{* * *} \mathrm{p}<0.01,{ }^{* *} \mathrm{p}<0.05,{ }^{*} \mathrm{p}<0.1$. 


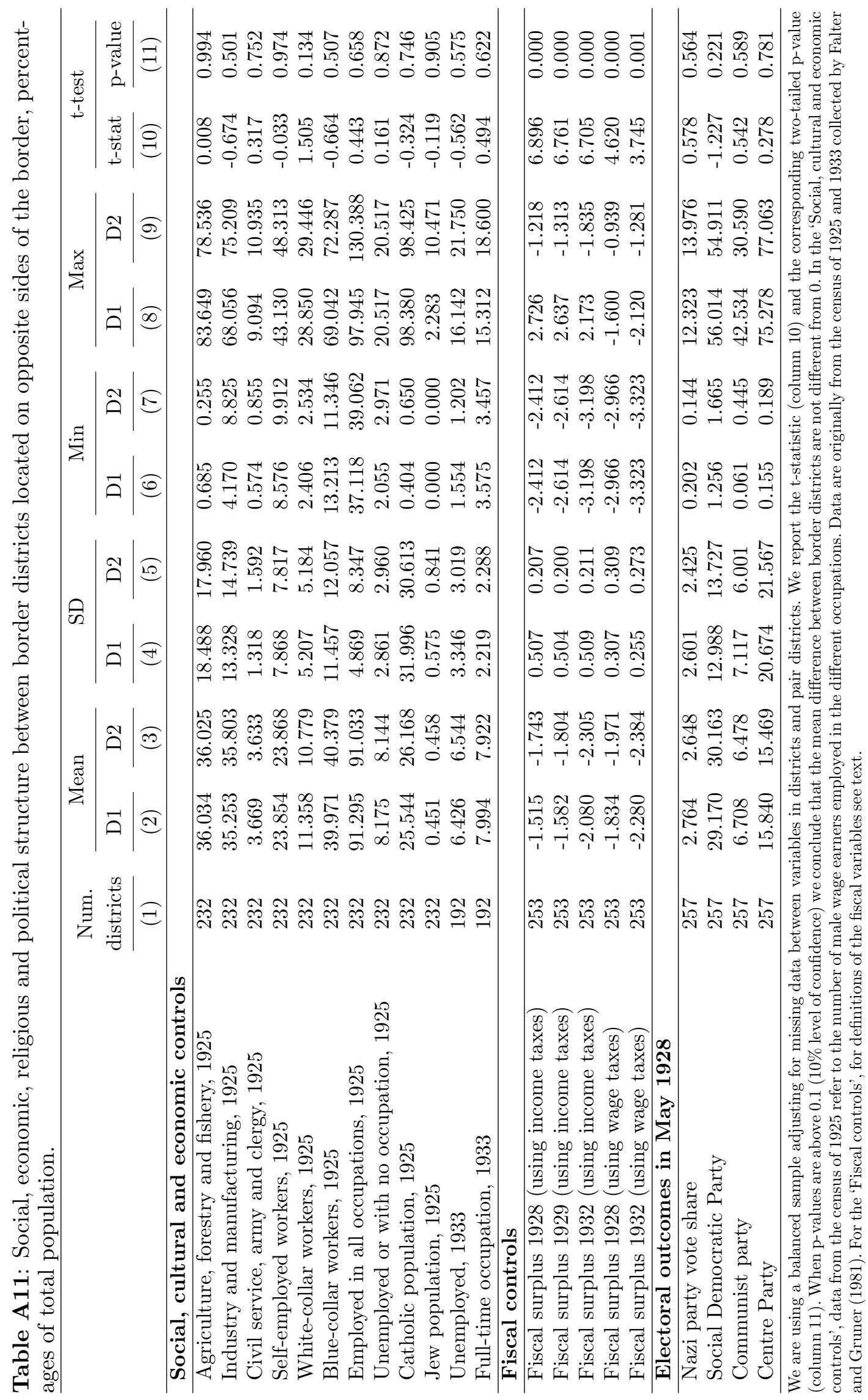


Table A12: Restricted sample of cross district-pairs located on opposite sides of the borders using the initial level of taxes as an instrument.

\begin{tabular}{lcccccc}
\hline & $(1)$ & $(2)$ & $(3)$ & $(4)$ & $(5)$ & $(6)$ \\
\hline Income taxes & $0.345^{* * *}$ & $0.345^{* * *}$ & $0.350^{* * *}$ & $0.350^{* * *}$ & $0.194^{* *}$ & $0.210^{* * *}$ \\
& $(0.079)$ & $(0.115)$ & $(0.081)$ & $(0.124)$ & $(0.079)$ & $(0.079)$ \\
Wages & & & $-0.450^{*}$ & -0.450 & & $-0.966^{* * *}$ \\
& & & $(0.246)$ & $(0.480)$ & & $(0.212)$ \\
Unemployment & & & $0.015^{* *}$ & 0.015 & & -0.008 \\
& & & $(0.007)$ & $(0.019)$ & & $(0.009)$ \\
Economic output & & & $0.676^{* * *}$ & $0.676^{* * *}$ & & $0.809^{* * *}$ \\
& 1,989 & 1,989 & 1,989 & 1,989 & 1,989 & $(0.108)$ \\
\hline Number of districts & 0.000 & 0.000 & 0.000 & 0.001 & 0.008 & 0.004 \\
\hline Anderson Rubin & 0.000 & 0.001 & 0.000 & 0.001 & 0.000 & 0.000 \\
Kleibergen-Paap & $\mathrm{X}$ & & $\mathrm{X}$ & & $\mathrm{X}$ & $\mathrm{X}$ \\
\hline Pair district clustering & & $\mathrm{X}$ & & $\mathrm{X}$ & $\mathrm{X}$ & $\mathrm{X}$ \\
State level clustering & & & & & & \\
Pair fixed effects & & & & & & \\
\hline
\end{tabular}

Dependent variable is the percentage share of the valid votes cast going to the Nazi party in the elections of July 1932, November 1932 and March 1933. For the years used in the controls see text. We cluster standard errors (in parentheses) at the district or state levels noted. We instrumented the change in the level of taxes paid with the taxes paid in 1928 . The first stage always shows the expected negative sign at it is statistically significant at $1 \%,{ }^{* * *} \mathrm{p}<0.01,{ }^{* *} \mathrm{p}<0.05,{ }^{*} \mathrm{p}<0.1$. 


\section{Data Sources}

We begin explaining our sources on the city-level data on electoral results, control variables, expenditures, population, unemployment, new residential apartments, and mortality. Data on electoral returns for the Reichstag elections of September 1930, 1932 (July and November) and March 1933 at the city level are from the official publication Statistik des Deutschen Reiches. These data have been previously used by other authors including Satyanath et al. (2017), and were initially collected and used by Falter et al. (1986). We used the updates made by Satyanath et al. (2017) to Falter's data which accounts for, amongst other things, changes in the names of cities across time.

Population, unemployment, number of new apartments, expenditure and taxes are newly collected from the Statistical Yearbooks of the German Municipalities. Until 1934 these statistical yearbooks were published as Statistisches Jahrbuch deutscher Städte and after 1934 under the name of Statistisches Jahrbuch deutscher Gemeinden. Data for all these variables were available for cities above 50,000 inhabitants reporting a panel of 98 cities. Although unemployment data were available for 248 cities we adjust the panel to cities above 50,000 inhabitants (when spending data and other controls are all available). For some 6 cities data were not reported for all the years (1928-1932) since they were close to the threshold of 50,000 inhabitants. For instance, data for the city of Neuß are only reported for 1931, 1932 and 1933 when the population was above 50 thousand individuals: 54.8 in 1931, 55.5 in 1923 and 55.8 in 1933. The same appears in the city of Ratibor with a population (in thousands) in 1931 of 50.5, 50.7 in 1932 and 51.8 in 1933.

Spending data (Ausgaben Insges. Einschl. Umlagen in 1,000 RM) are reported by fiscal years, which runs from the first day of April in a year to the last day of March in the following year. Data adds the ordinary and extraordinary budget and all level of expenditure. In the statistical analysis we removed the city of Solingen (an independent city Stadtkreise in the state of North Rhine-Westphalia) as a potential outlier. Regarding spending data by budget category, General Administration includes expenditures on general administration, police and security. Education combines spending on elementary school, secondary schools, middle schools, higher schools and other school systems including spending on science and art and church. Health and wellbeing adds data on healthcare and healthcare facilities, welfare and relief. Construction adds construction management and civil entering, spending on transport and general economic development. Spending on public infrastructures adds data on street cleaning and lighting, parks, cemeteries, cleaning of canals, sewage and drainage and finally, Housing combines data on housing and settlement. For the later years instead of the totals for these five categories data were reported in more disaggre-gated categories. However, to have a consistent panel we just add the more disaggregated categories into these 5 meaningful categories reported in 1929.

Population data refers to the level of population (nationals and non-nationals) at the beginning of the year (1st of January), with the exception of 1933 that was reported at 16 June 1933. Unemployment data are given at the end of the year (31 December) with the exception of 1933 that was reported at 28 February of 1934. A worker is defined as unemployed if the 
worker is part of the labor force but not working and it is registered in the local offices as an unemployed person. To proxy economic output we use the yearly construction of new apartments on residential buildings (Neuerstellte Wohnungen in Wohngebauden). We note that the construction of new residential apartments moved closely with the development GDP (for instance see Ritschl 2013a, Tab. 4.4).

We use the weekly bulletins of the Reichs-Gesundheitsblatt to collect a new city level panel of weekly high-resolution mortality data for over 23 causes of death. Weekly data have been aggregated into yearly data and are available for cities with a population larger than 100,000 inhabitants. In total the panel is based on 51 cities. Since the Reichs-Gesundheitsblatts also provide population figures (instead of weekly reported population figures change every two-three months) we calculate crude death rates with the mid-year population weighting the number of deaths of a certain cause by the city-population (in thousands). We also use the data on infant deaths (deaths below the age of 1 not including stillbirths) to calculate the city level infant mortality rates weighting the infant deaths by the number of city births which are also reported in the health bulletins.

We next move to district level data. Data on electoral returns for the Reichstag elections of September 1930, 1932 (July and November) and March 1933 at the district (kreis) level are from the official publication Statistik des Deutschen Reiches (Wahlen zum Reichstag's volumes). Data were initially collected and used by Falter et al. 1986. We used the updates made by Satyanath et al. (2017) to Falter's data which accounts for, amongst other things, changes in district borders.

Income taxes are newly collected form Die Einkommen- und Körperschaftsteuerveranlagungen and wage taxes are newly collected from Der Steuerabzug vom Arbeitslohn (which both are reported under the official Statistik des Deutschen Reichs). The Reich statistical books provide state and district (kreis) level data on the number of taxpayers, total taxable income, and total revenue (in 1,000 RM) on income and wage taxes. For income taxes at the district level we use the data from Teil I Abschnitt A, Einkommensteuerveranlagung, Steuerpichtige, Einkunfte und festgesetzte Steuer and for wage taxes at the district level the data from Teil I Abschnitt A, Lohnsteuerpichtige, (soweit nicht veranlagt): Steuerbelastete, Steuerbefreite, Unbesteuerte. In the next page we show the spatial distribution of the change in income taxes between 1929/1932.

Government spending data are newly collected from Die Ausgaben und Einnahmen der offientlichen Verwaltung im Deutschen Reich (which are reported under the official Statistik des Deutschen Reichs). These books provide state level data on central, state and municipal spending (in 1,000 RM). Data for unemployment are the number of unemployed workers in a state as given in the official Statistisches Jahrbuch für das Deutsche Reich. A worker is deffined as unemployed if the worker is part of the labour force but not working. For each year we created a state-level index of nominal wages arithmetically averaging the monthly data from the hourly wages paid in four occupations: construction (Bauarbeite), wood (Holzarbeiter) and skilled and unskilled workers in metallurgy (Metallarbeiter). This index is based on 38 big cities that consistently reported data between 1929 and 1933 and each city has been located within each of the states. Data are in Rentenpfennig (Rf) (1 
Rentenmark $=100$ Rentenpfennig) and were newly collected from the official Statistisches Jahrbuch für das Deutsche Reich. Throughout we use the natural logarithm of this index in a state or the percentage change. ${ }^{1}$

Economic output is proxied by the generation of electricity under the assumption that the vast majority of manufactured goods and services are produced using electricity. Data are at the state level, measured in 1,000 kWh and were newly collected from the official Statistisches Jahrbuch für das Deutsche Reich. Throughout we use the natural logarithm of this variable or percentage changes.

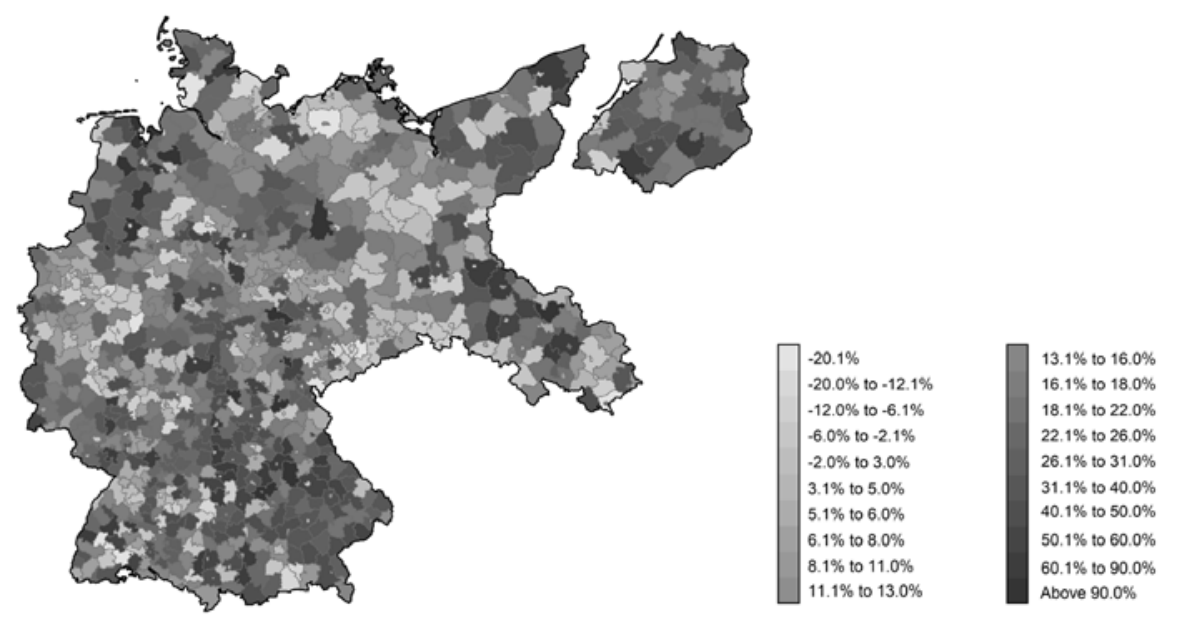

\footnotetext{
${ }^{1}$ The 38 cities are: Aachen, Altona, Augsburg, Barmen, Berlin, Bochum, Brandenburg, Braunschweig, Bremen, Breslau, Chemnitz, Dortmund, Dresden, Duisburg, Dusseldorf, Erfurt, Essen, Frankfurt a. M., Gelsenkirchen, Hagen, Halle a. S., Hamburg, Hannover, Karlsruhe, Kassel, Kiel, Köln, Königsberg, Leipzig, Magdeburg, Mannheim, Munchen, Nürnberg, Remscheid, Solingen, Stettin, Stuttgart, and Wuppertal.
} 